\title{
高速載荷を受ける主鉄筋で補強したコンクリート製砂防 ダム袖部模型の動的挙動と個別要素法による破壊解析
}

\author{
鈴木真次 $1 \cdot$ 石川信隆 $2 \cdot$ 石川芳治 $3 \cdot$ 水山高久 $4 \cdot$ 古川浩平 5 \\ 1 正会員工修 防衛大学校研究員 土木工学科 (テ2 39 神奈川県横須賀市走水 1-10-2 0)

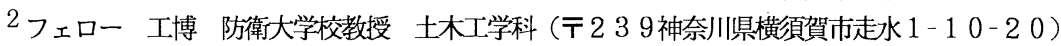 \\ 3 正会員 農博 京都府立大学助教授 農学部林学科（前建設省土木研究所秒防研究室長） \\ （宁６００６京都市左京区下鴨半木町 1) \\ 4 正会員 農博 京都大学教授 農学部林学科 ( \\ 5 正会員 工博. 山口大学教授 工学部社会建設工学科（テ7 55 山口県宇部市常盤台 2557 ）
}

\begin{abstract}
本研究は，主鉄筋のみで補強したコンクリート製砂防ダム袖部の耐衝撃設計に資するため，まず複鉄筋および単鉄 筋の鉄筋量を変化させて主鉄笳で補強したコンクリート製砂防ダム袖部模型の静的および高速載荷実験を行い，主鉄 筋量か耐力およひ変形性能に与える影響や破壊モードに与える影響について調へた. その結果, 主鉄筋量の少ない供 試体では曲け破壊か栍じ, 静的載荷に比へ高速載荷では終局変位か大きく減少した. また, 主鉄筋量の多い場合はせ ん断ひび割れ破壊か甡じた. 次に, 実験結果をシミュレートするため, RC用の個別要素法 (DEM) を開発し, 解 析による破壊過程を高速ビデオによる実験結果と比較し，極めて良く一致していることを確かめた．
\end{abstract}

Key Words: concrete check dam wing, longitudinal reinforcement, high speed loading, area of reinforcement, distinct element method, failure analysis, high speed video

\section{1. 緒言}

コンクリート製砂防ダムは, 急流河川域て数多く建設 されているが，そのほとんどは無筋で造られているため, 土石流中の巨磁の衝突によりその袖部がしばしば破壊 される例が見られる ${ }^{1)}$. 袖部は, 土石流や泥流を安全に 河道中央に導き，ダムの基礎部を保護する重要な役目を 果たすものであり，袖部の破壊は本堤の破壊につながり かねない：このため，平成元年に鉄筋で補強することが 提案された2)が，その効果は十分解明されていない.

これまで著者らは，水平衝突実験装置を用いて主鉄筋 で補強したコンクリート製砂防ダム袖部に対する模型 衝突実験 ${ }^{3)}$ を行い，その終局限界を実験的に解明してき た．その結果，袖部の終局限界を根元部におけるひび割 れ連結と定義した. しかし，この実験では鉄筋量が比較 的少なかったため，主として曲げひび割れ破壊のみが生 起し，鉄筋量を変化させた場合については未解明であっ た.

一方, 従来のR C 部材に関する衝撃研究は, 衝撃速度 の極めて早いものから低速のものまで，極めて数多くな されているが4) 13), 本研究は土石流中の巨礫を対象之 したもので, 衝突体の重量が約 1 tonf〜 10 tonf で, 速 度が最大でも $10 \mathrm{~m} / \mathrm{sec}$, 通常約 $5 \sim 6 \mathrm{~m} / \mathrm{sec}$ と比較的
遅いため，ひずみ速度が $10^{-1} \sim 10 \% \mathrm{sec}$ の中間ひずみ速 度 ${ }^{13)}$ の範疇亡考えられる. また, 土石流中の巨砅は単独 ではなく複数で流体の中にくるまれて衝突するため, 一 般の衝突と比へ衝突体が停止しにくく, 高速載荷 ${ }^{13)}$ 状 態（巨砂が衝突後一定速度で構造物に変形を与える状 態）亡似たものになる可能性が大きく, 落石等の衝突亡 は異なるものと考えられる，すなわち，土石流による主 鉄筋で補強したコンクリー-卜製砂防ダム袖部の動的応 答特性を求めるには, 高速載荷実験により袖部がどの程 度まて耐えられるか，いわゆる耐力と変形性能の動的終 局限界およびそのときの破壊モ一ドを調べる必要があ る.

このような観点から, 本研究は, 複鉄筋および単鉄筋 の鉄筋量を変化させた主鉄筋で補強したコンクリート 製砂防夕゙ム袖部の模型に対して, まず静的および高速載 荷実験を行い，主鉄筋量か耐力および変形性能に与える 影響や破壊モ一ドに与える影響について調べた。ここで は，主鉄筋量による破壊モ一ドの違いを調べるため，せ 儿断補強筋をあえて導入しなかった，その理由は， RC 構造としては当然せん断補強筋を導入すべきであるが, 施工現場が通常山奥に点在し, 従来無筋であったコンク リート製砂防夕゙ム断面に対し鉄筋を導入する場合，なる べく鉄筋工を多く必要としない構造の要求が多く，せん 


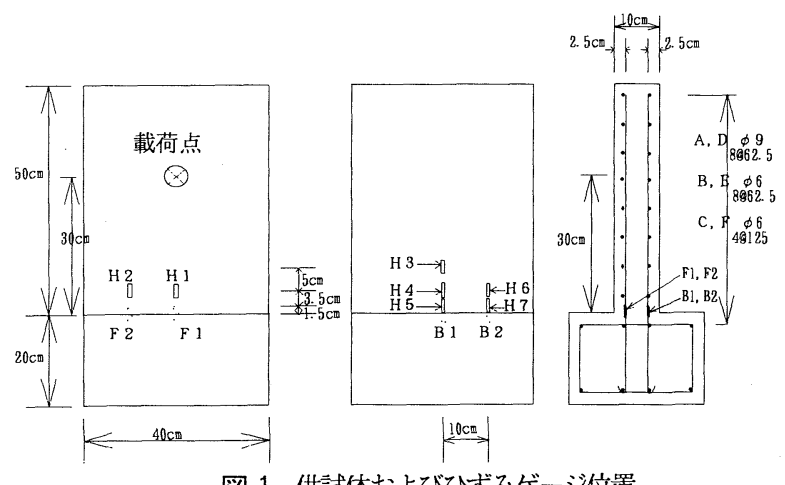

図-1 供試体およびひずみゲージ位置

表-1 材料諸元

\begin{tabular}{|l|l|}
\hline \multicolumn{2}{|l|}{ モルタル } \\
\hline セメント & $549 \mathrm{~kg} / \mathrm{m}^{3}$ \\
\hline 水 & $295 \mathrm{~kg} / \mathrm{m}^{3}$ \\
\hline 細骨材 & $1372 \mathrm{~kg} / \mathrm{m}^{3}$ \\
\hline 水セメント比 & $53.7 \%$ \\
\hline 最大压縮強度 & $367 \mathrm{kgf} / \mathrm{cm}^{2}$ \\
\hline $\begin{array}{l}\text { 最大王縮強度 } \\
\text { 発生時ひずみ }\end{array}$ & $3900 \mu$ \\
\hline 鉄筋 \\
\hline 規格 & $\mathrm{SR235}$ \\
\hline 降伏点 & $3449 \mathrm{kgf} / \mathrm{cm}^{2}$ \\
\hline 引張強さ & $4480 \mathrm{kgf} / \mathrm{cm}^{2}$ \\
\hline 伸び & $33.3 \%$ \\
\hline
\end{tabular}

（ただし, $1 \mathrm{kgf}=9.8 \mathrm{~N}$ )
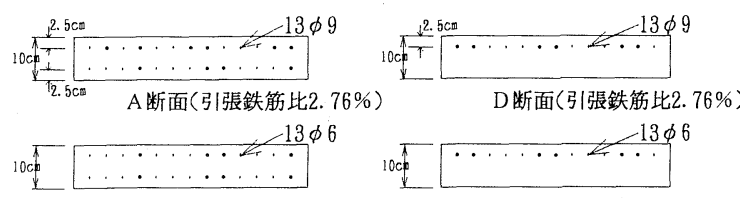

$\mathrm{B}$ 断面(引張鉄筋比 $1.26 \%$ )

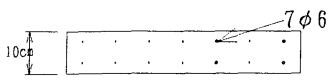

C 断面(引張鉄筋比 $0.67 \%$ )

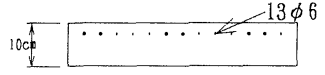

$\mathrm{E}$ 断面(引張鉄筋比1.26\%)

(a)複鉄筋

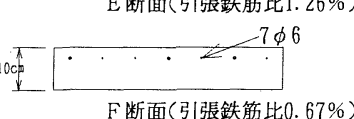

(b)単鉄筋

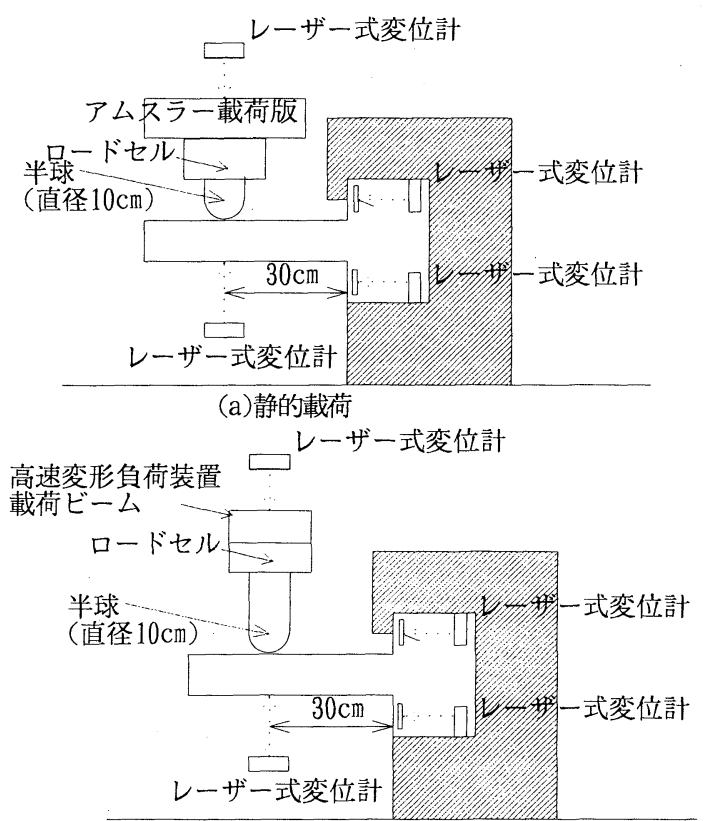

（b）高速載荷

図-3 載荷実験

通っており，ただ静的載荷と異なる点は載荷速度のみで， 供試体を必ず破壊させるので， R C 部材の動的終局限界 を求めることができる. 主鉄筋で補強したコンクリート 製砂防夕゙ム袖部に対する高速載荷実験はほとんどなさ れておらず，土石流による主鉄筋で補強したコンクリー 卜製砂防ダム袖部の破壊メカニズムを解析する上で必 要不可欠である.

なお，RC部材の衝撃実験や衝撃応答解析についても， 未だ精密な実験デー夕が十分蓄積されているわけでは なく，また材料構成則についても明確な定式化がなされ ていない現状であるが, 本研究はなるべく精密な実験を 行い，その結果を用いて簡単でしかも精密な破壊モ一ド が得られるDEMモデルの開発を試みたものである.

\section{2. 静的載荷および高速載荷実験}

本実験では，R C 部材の耐衝擊性に最も影響を及ぼす と考えられる引張鉄筋比をパラメー夕として，複鉄筋と 単鉄筋のそれぞれの場合に対して静的および高速載荷 実験を行う．本実験の目的は，主鉄筋で補強したコンク リート製砂防ダム袖部の耐衝撃設計における一つの設 計基準（破壊基準）を設定するための基礎的資料を得る ため，荷重～変位関係を求めるとともに，終局限界およ ひ破壊モ一ドを調べるものである，なお，本実験では， 供試体にせん断補強筋を導入しなかったが，その理由は， 緒言で述べたおり，ここでは主鉄筋の鉄筋量のみによ る破壊モードの違いを調べるためである. 
表-2 供試体の種類と鉄筋比

\begin{tabular}{|c|c|c|c|}
\hline 種類 鉄筋比 & 断面夕イプ & 引張鉄筋比 & 釣合鉄筋比 \\
\hline \multirow{2}{*}{$\begin{array}{c}\text { 複 } \\
\text { 鉄 } \\
\text { 筋 }\end{array}$} & Aタイプ & $2.76 \%$ & $4.92 \%$ \\
\cline { 2 - 4 } & Bタイプ & $1.26 \%$ & $4.92 \%$ \\
\hline \multirow{2}{*}{$\begin{array}{c}\text { 単 } \\
\text { 鉄 } \\
\text { 筋 }\end{array}$} & Cタイプ & $0.67 \%$ & $4.92 \%$ \\
\cline { 2 - 4 } & Dタイプ & $2.76 \%$ & $4.92 \%$ \\
\cline { 2 - 4 } & Eタイプ & $1.26 \%$ & $4.92 \%$ \\
\hline
\end{tabular}

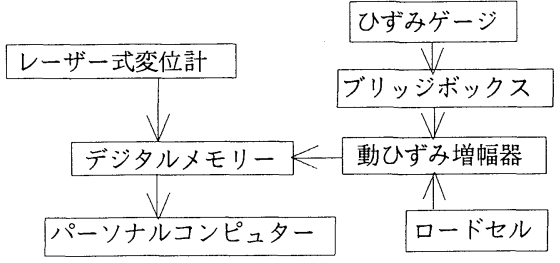

図-4 計測システム

\section{(1)実験方法}

\section{a)供試体諸元と実験パラメータ}

供試体は，実際の主鉄筋で補強したコンクリート製砂 防ダム袖部の約 $1 / 10$ 模型として, 図-1 に示すように長 さ $50 \mathrm{~cm}$ ，厚さ $10 \mathrm{~cm}$, 幅 $40 \mathrm{~cm}$ の複鉄筋および単鉄筋の片 持ちスラブである，実験の均一性を図るため，本実験で はコンクリートの代わりにモルタルを使用し，圧縮強度 を $367 \mathrm{kgf} / \mathrm{cm}^{2}$ とした. 材料諸元を表-1 に示す. また本実 験のパラメー夕は，引張鉄筋比 $(2.76 \%, 1.26 \%, 0.67 \%)$ であり，供試体を図-2 に示すように 6 種類に分類した. ここで，モルタルの打設は一回で行い（打継ぎなし）， 鉄筋は先の衝突実験 ${ }^{3)}$ と同じ材料を用い主方向筋を図-1 に示すように横方向筋により接続（溶接）した. さらに 静的亡高速載荷の 2 種類の載荷を行い 計 12 種類，一種 類に対して 2 体の実験を行うため合計 24 体の供試体 を作製した，供試体の種類と鉄筋比の一覧を表-2 に示す。

\section{b)載荷方法}

本実験では，供試体への載荷方法として図-3(a)，(b) に示すように片持ち R C スラブを横にして上方より静 的および高速載荷を行った，本来，主鉄筋で補強したコ ンクリート製砂防ダム袖部は, 縦にして水平より載荷す べきであるが，高速載荷装置の制約（上方から載荷とい う）から上記の載荷方法を採用した，なおこのことに よる影響は， R Cスラブ自体の自重が複鉄筋の場合の最 も重い供試体 Aでも約 $50 \mathrm{kgf}$ であり,最大荷重の約 5.5tonf と比へ約 $1 \%$ 程度であり，自重の影響は小さい ものと判断した.

載荷位置は，片持ちスラブの固定部根元から $30 \mathrm{~cm}$ の 位置（これは土石流時における最も被災例の多い水深 ${ }^{1)}$ $3 \mathrm{~m}$ より決定した）にアムスラー試験機および高速変形負

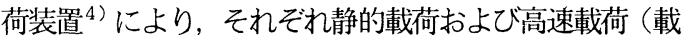
荷速度 $4.0 \mathrm{~m} / \mathrm{sec}$ ）した. また載荷点の状況は, 先端形状
表-3 計測機器の性能・諸元

\begin{tabular}{|c|c|c|}
\hline 計測項目 & 計測機器名称 & 性能・諸元 \\
\hline 変位 & レーザー式変位計 & $\begin{array}{l}\text { 測定範囲 : } 200 \mathrm{~mm} \\
\text { 応答周波数 : } 915 \mathrm{~Hz}\end{array}$ \\
\hline ひずみ & ひずみゲージ & $\begin{array}{l}\text { ゲージ率: } 2.13 \\
\text { 抵抗值: } 12.4 \pm 0.4 \Omega\end{array}$ \\
\hline 荷重 & $\begin{array}{l}\text { 荷重変換機 } \\
\text { (ロードセル) }\end{array}$ & $\begin{array}{l}\text { ひずみゲージ式 } \\
\text { 測定容量 : 50tonf }\end{array}$ \\
\hline & 動ひずみ増幅器 & 応答周波数 : DC 200kHz \\
\hline & デジタルメモリー & $\begin{array}{l}\text { 応答周波数: } \mathrm{DC} \sim 250 \mathrm{kHz} \\
\text { 分解能 } 8,12 \text { bit }\end{array}$ \\
\hline
\end{tabular}

直径 $10 \mathrm{~cm}$ の半球状の載荷棒による点載荷である．供試 体の固定方法は, 図-3に示すように供試体の固定部にフ 一チングを設け，これを固定治具で挟み込み，ボルト（ $10 \mathrm{~mm}, 4$ 本) で締め動かないように固定した.

\section{c)実験計測}

測定項目は, 静的および高速載荷時それぞれ図-3に示 すように，いずれも載荷点荷重，載荷点上変位（載荷ビ 一ム)，載荷点下変位，コンクリートおよび鉄筋のひず みである．載荷点荷重は，ロードセル（ひずみゲージ式 最大容量 50tonf）により，また上，下変位はレーザー式 変位計で，さらにコンクリートおよび鉄筋ひずみゲージ を用いてひずみを計測した．計測システムの構成図を図 -4に示し, 使用した計測機器の主要性能諸元を表-3に示 す.

なお，高速載荷実験の継続時間は数10msecであるため， 本システムでは測定時間を $90 \mathrm{msec}$ 之設定し；デジタル メモリーのサンプリング間隔 $\Delta t$ を $\Delta t=20 \mu \mathrm{sec}$ とした. これにより測定可能な応答周波数を $10 \mathrm{kHz}(=100 \mu \mathrm{sec})$ とすると，最小振動波形を 5 点で近似測定することにな り，衝撃的現象を十分な精度で測定できるものと考えた また，横方向から高速ビデオ（1 sec に1000 コマ）に より破壊状況を撮影した。

\section{(2)実験結果および考察}

ここでは，静的載荷と高速載荷の載荷方法の相違，引 張鉄筋比による相違および複鉄筋と単鉄筋による相違 がそれぞれ荷重〜変位関係および破壊モ一ドに与える 影響について調べる．なお，高速載荷の場合の荷重〜変 位関係は，荷重～時間曲線亡変位～時間曲線から時間軸 を同調して求めたものである.ここで，変位は上変位と 下変位を測定したが，ここでははり全体の変位を示すた めに上変位を示した

\section{a)載荷方法の相違力荷重～変位に与える影響}

図-5(a)，（b），(c)は，複鉄筋の場合のA，B，C夕 イプの荷重〜変位関係を静的と高速載荷とを比較して 示したものである．高速載荷の方か清争的載荷に比し最大 荷重か約 1.5 3.5 倍大きくなっている.この原因は通 


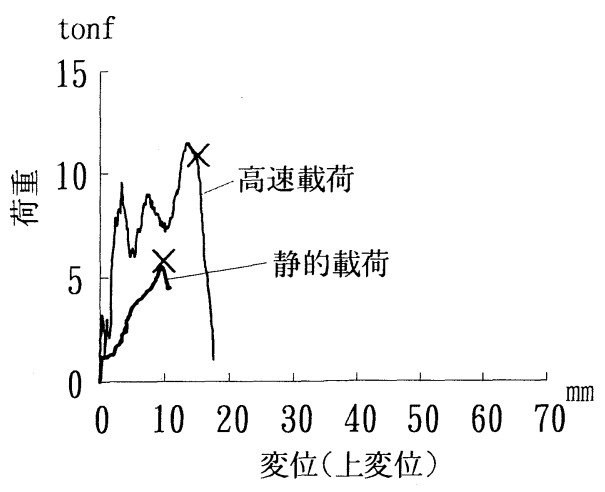

(a)Aタイプ

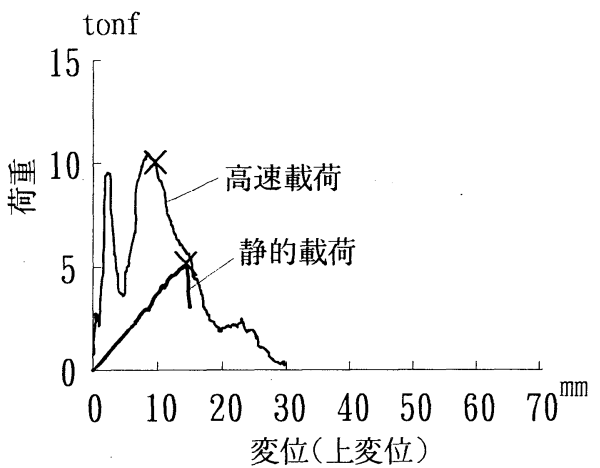

(b) Bタイプ

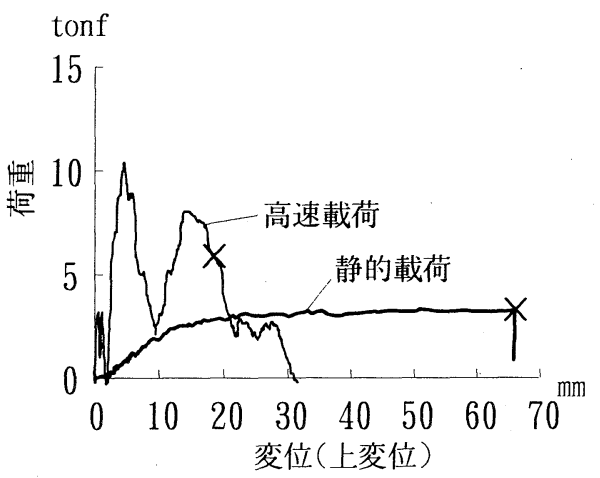

(c) Cタイプ

図-5 複鉄筋の各夕イプにおける荷重〜変位関係

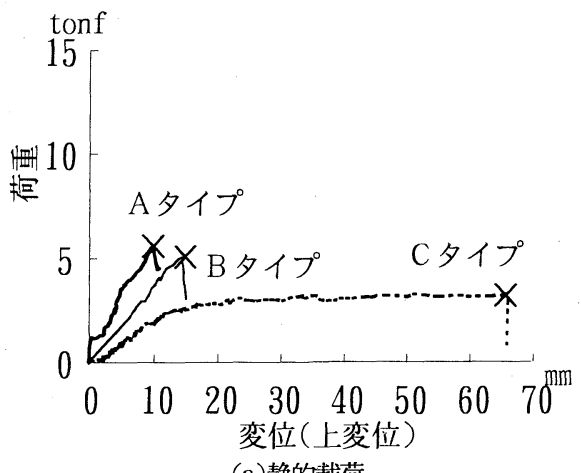

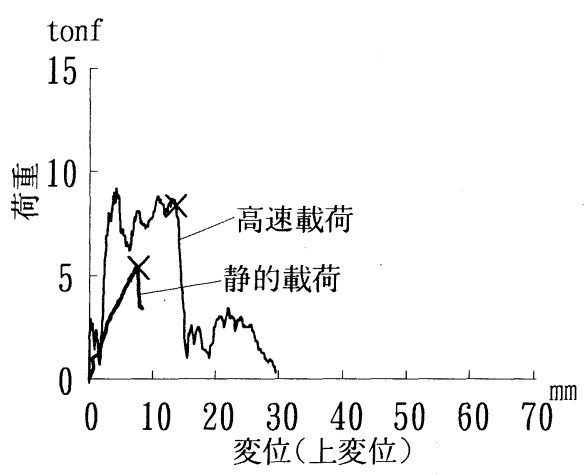

(a)Dタイプ

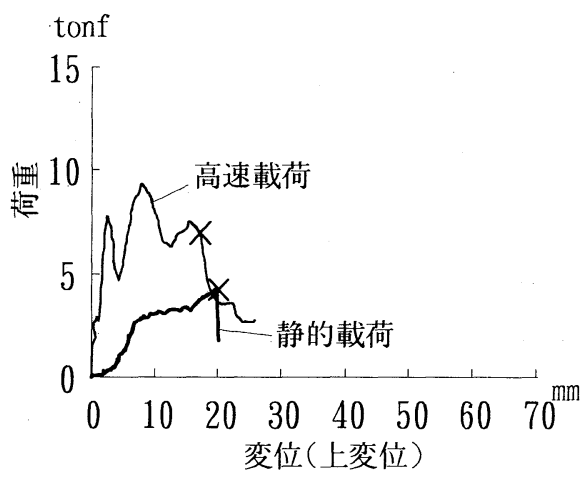

(b) Eタイプ

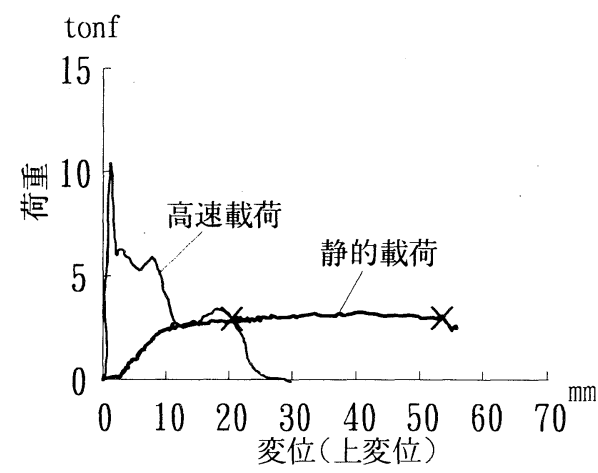

(c) Fタイプ

図-6 単鉄筋の各夕イプにおける荷重〜変位関係

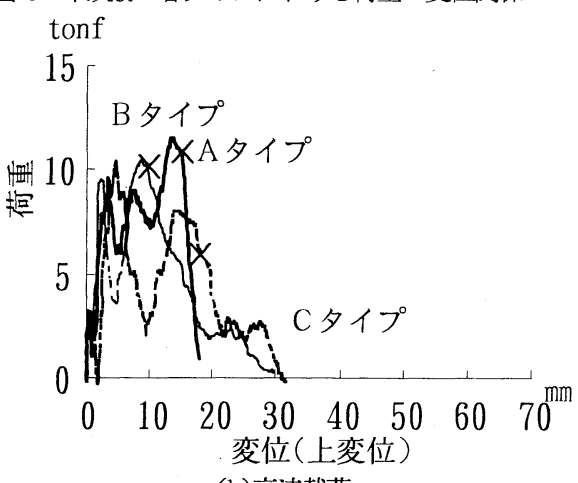

(b)高速載荷

図-7 複鉄筋夕ヘプにおける鉄筋比による荷重〜変位関係の比較 
表-4 供試体の曲け耐力とせん断耐力

\begin{tabular}{|c|c|c|c|}
\hline \multirow{2}{*}{$\begin{array}{l}\text { 断 } \\
\text { 面 }\end{array}$} & \multirow[t]{2}{*}{ 断面 } & \multicolumn{2}{|l|}{ 静的載荷 } \\
\hline & & 曲け耐力 & せん断耐力 \\
\hline 複 & Aタイプ & 8. 83tonf & 5. 95tonf \\
\hline 鉄 & Bタイプ & 7.67tonf & 4.54onf \\
\hline 䈘 & Cタイプ & 3. 41tonf & 3. $70 \mathrm{onf}$ \\
\hline 単 & Dタイプ & 8. 57 tonf & 5. 95 tonf \\
\hline 鉄 & Eタイプ & 7.67tonf & 4.54onf \\
\hline 筋 & Fタイプ & 3.36tonf & 3. 70onf \\
\hline
\end{tabular}

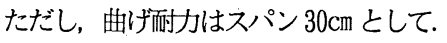

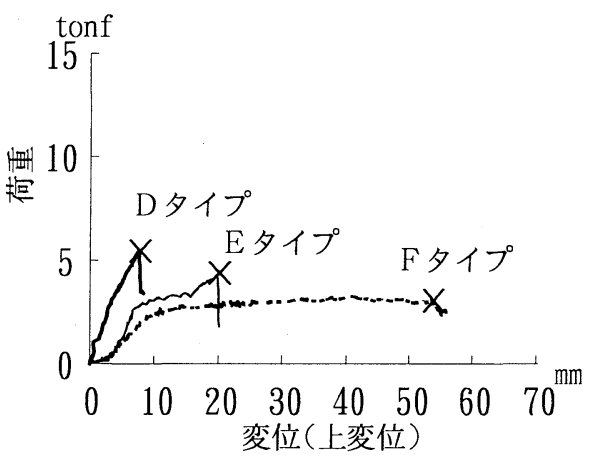

(a)静的載荷

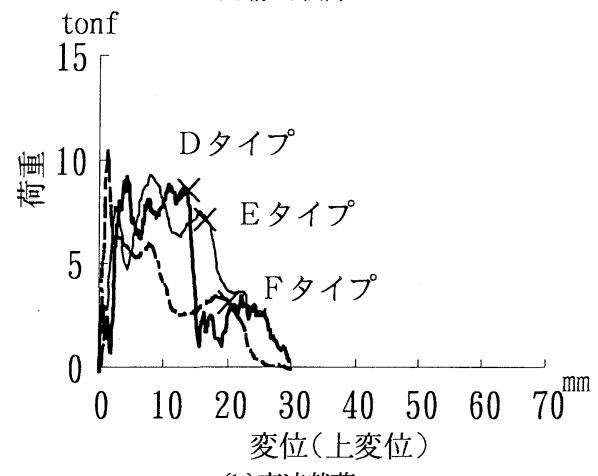

(b)高速載荷

図-8 単鉄筋夕イプにおける鉄筋比による荷重〜変位 関係の比較

常いわれているひずみ速度効果によるものと思われる. しかし, 高速載荷の終局変位（図中の×印）は, B夕イ プ，Cタイプとも静的載荷に比し小さくなっており,特 にCタイプの場合は約 $1 / 3$ に減少している. この理由は, 後にも検討するが静的載荷の場合の終局限界が曲げに よる鉄筋の破断によるモードになっているのに対し, 高 速載荷の場合は, 根元部裏面のコンクリートの圧壊に起 因しており, 破壊モードの違いによるものである.

また, 高速載荷の場合, 荷重の山がAタイプでは3つ B，Cタイプでは2つ現れているが，この理由は高速載 荷の場合, 後の図-9(a)にも示すように約 $10 \mathrm{msec}$ の間に $\mathrm{RC}$ 供試体か慣性力によって振動し，その影響により載 荷棒と供試体との間が離れる現象が現れたものと思わ

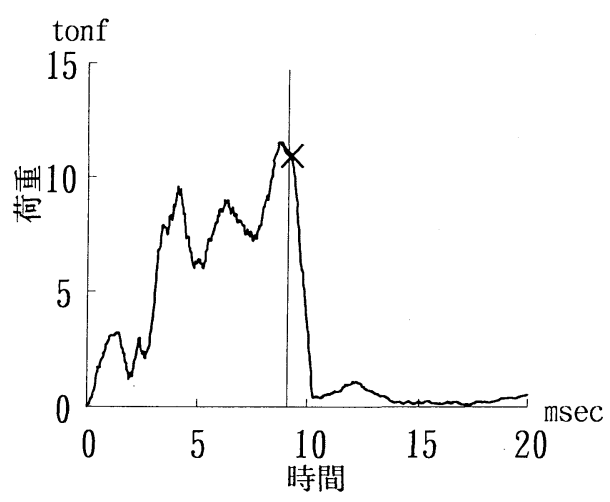

(a)荷重 時間関係

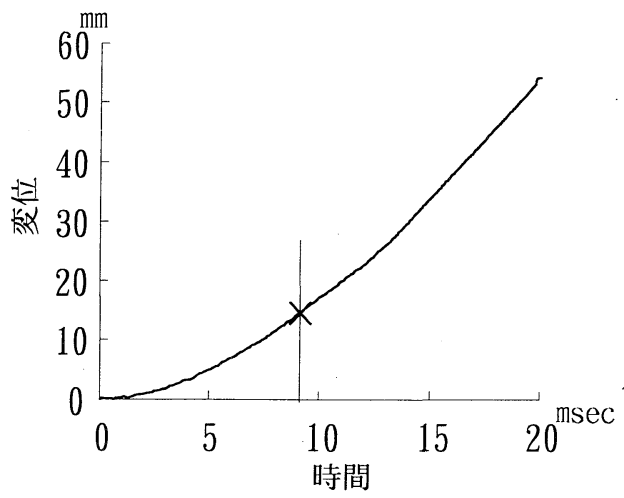

(b)変位～時間関係

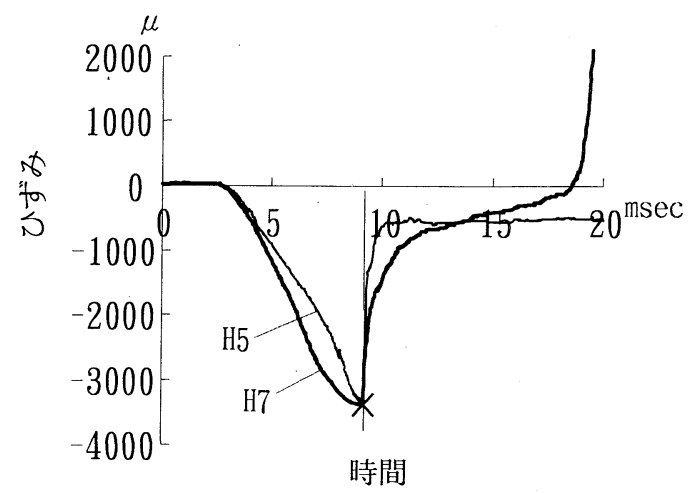

(c)ひずみ〜時間関係

図-9 Aタイプ高速載荷における荷重, ひずみ〜時間関係

れる.

図-6(a)，（b)，(c)は，単鉄筋の場合のD，E，F夕 イプの荷重〜変位関係を示したもので, 図-5の場合とほ ぼ同様の傾向を示している. 特に, Fタイプは曲け破壊 であり, 図-5(c)のCタイプと同様に，最終の破壊モード の違いにより高速載荷の終局変位は静的載荷に比べ約 1/2.5に小さくなっている.

\section{b)引張鉄筋比の相違か荷重 変位関係に与える影響}

図-7(a)，(b)は, 複鉄筋の引張鉄筋比をパラメー夕と 


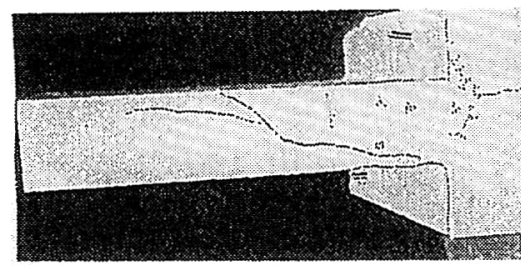

Aタイブ

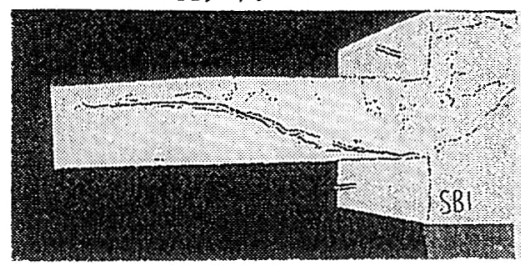

Bタイブ

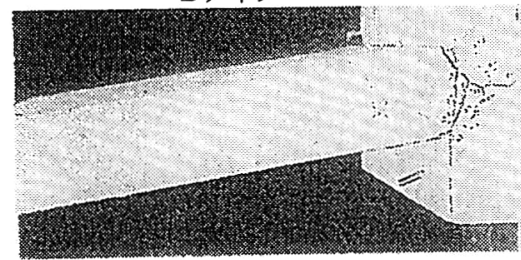

Cタイブ

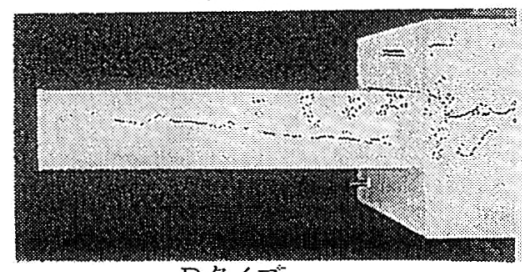

Dタイブ

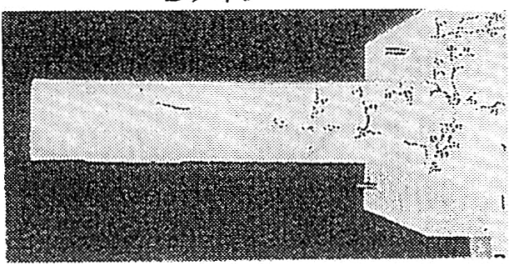

Eタイブ

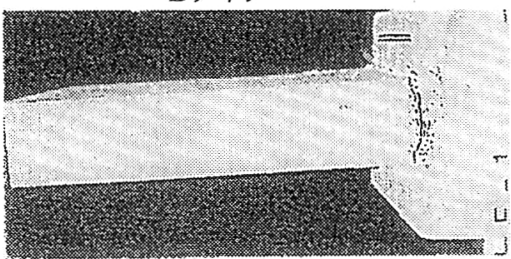

Fタイプ

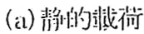

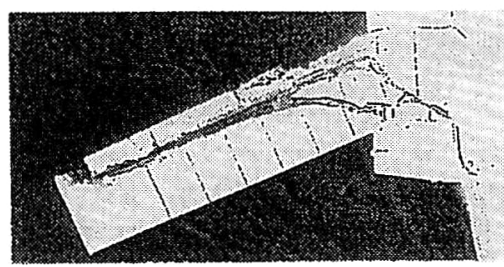

Aタイプ

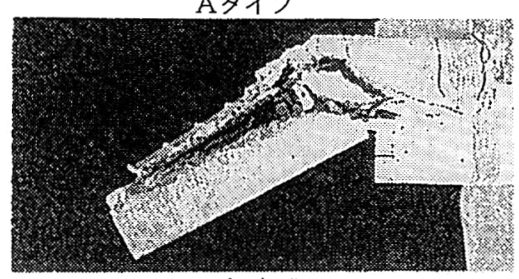

Bタイブ

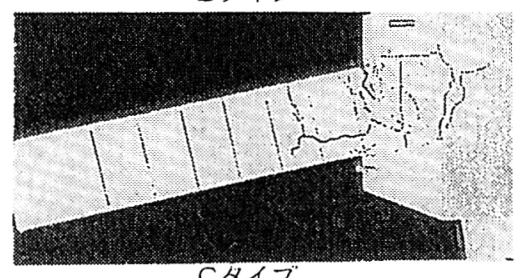

C.タイフ

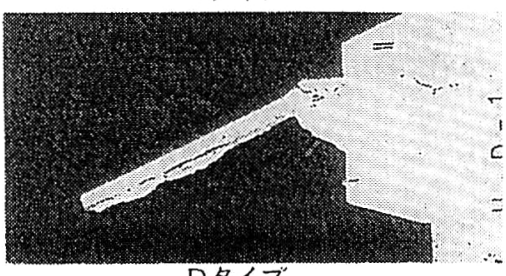

Dタイブ

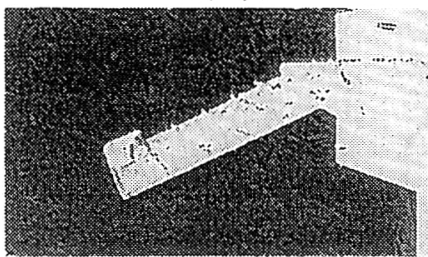

Eタイプ

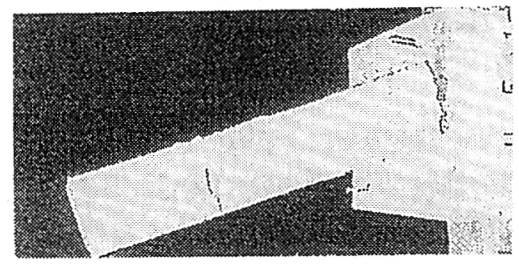

Fタイブ

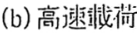

写真-1 答タイプ佊装状沅

したときの荷重〜变位関係を示したものである.こ机よ り, 引㖘鈔筓比の大きいA，B夕イプの高速载荷洔の最 大荷重は約 11 tonf で静的载荷の約 5 tonf に比し約 2.2 倍之酎力が上昇している。 しかし，A，B两都に耐力の 差はあまりなく，終局桨位む概社約 $15 \mathrm{~mm}$ 程度であまり 㾤がないことが認められた。 こ㧈は，写真-1および図一
10，11に示すように阔タイプと屯載荷点から根元部稟面 を結ぶような斜めひび割狆が入るせん断破㜔を生じた

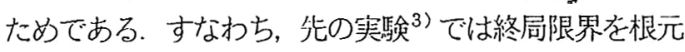
部のひび割扟連結と定䇅したが，ここでは根元部のみで なく载荷点と根元部裹面を結ぶようなひび割狆連結も 終局限界之定義することができる．またこのせん断破壊 


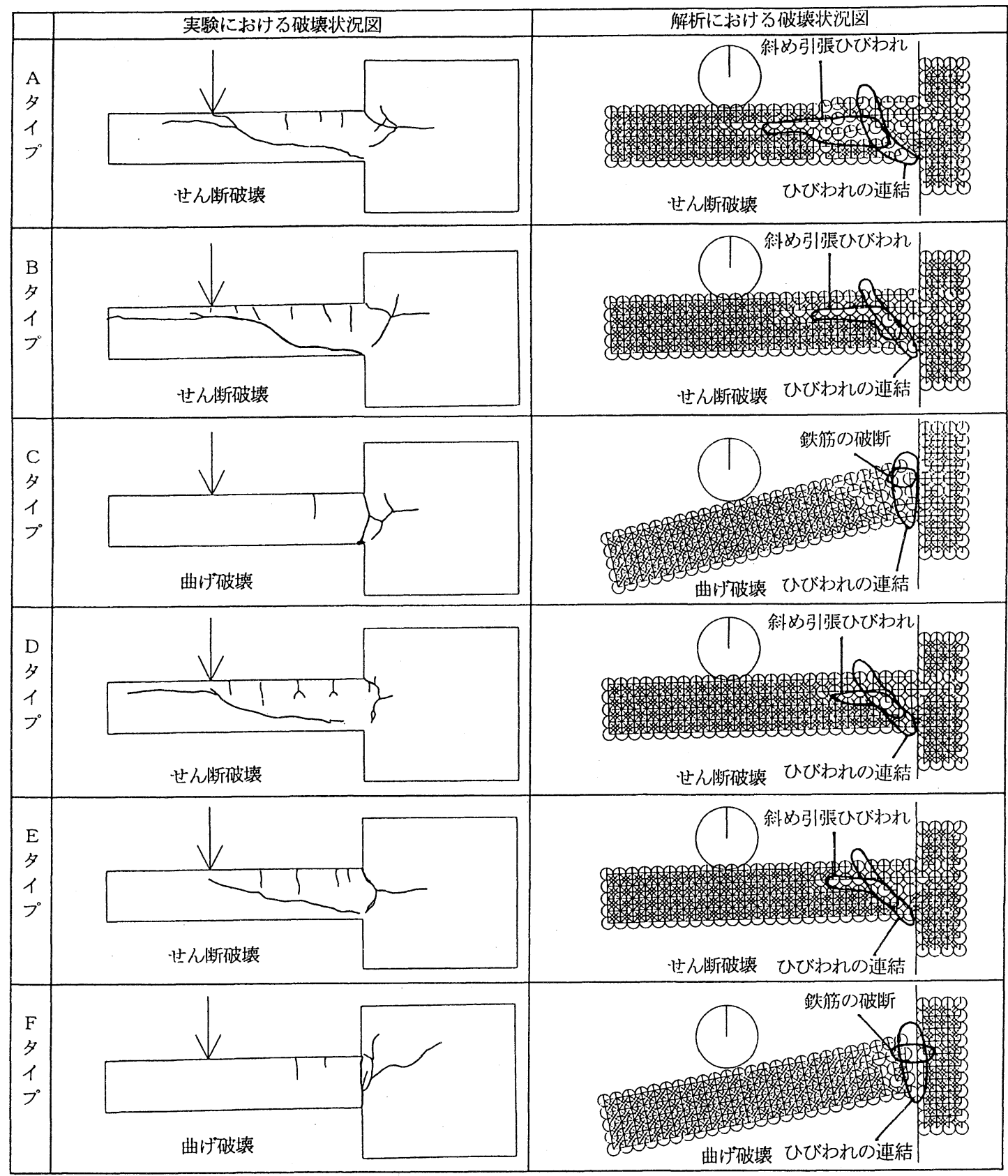

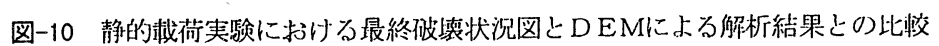

モードに主鉄筋量はあまり影響しないため，ほぼ同じ耐 力になったもの之考えられる. 一方，主鉄筋量の少ない Cタイプでは, 静的載荷の場合A, B夕イプに比し最大 荷重は約 40\%小さいが，終局変位は約 4 小 倍大きくな っている.これは，Cタイプの場合せん断耐力よりも曲 げ耐力が小さかったため曲け破壊が先行したものと考 えられる. このことは，静的な曲け耐力およびせん断耐 力の值をそれぞれ断面を分割し平面保持の仮定の下で

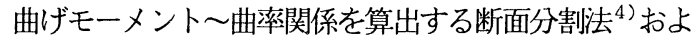
び二羽ら ${ }^{14)}$ の提案するせん断補強筋の無い場合のせん 断耐力式を用いて推定してみると表-4のとおりとなり, この結果を見るとCタイプの曲け耐力が 3.41tonf であ るのに対しせん断耐力は 3. 70 tonf となり, 曲け耐力が 小さいため曲け破壊が生じたためと推定される. また, 図-7(b)の高速載荷の場合Cタイプの終局変位が極度に 減少した（静的載荷の約 $1 / 4 ）$ 理由は, 静的載荷のC 夕 


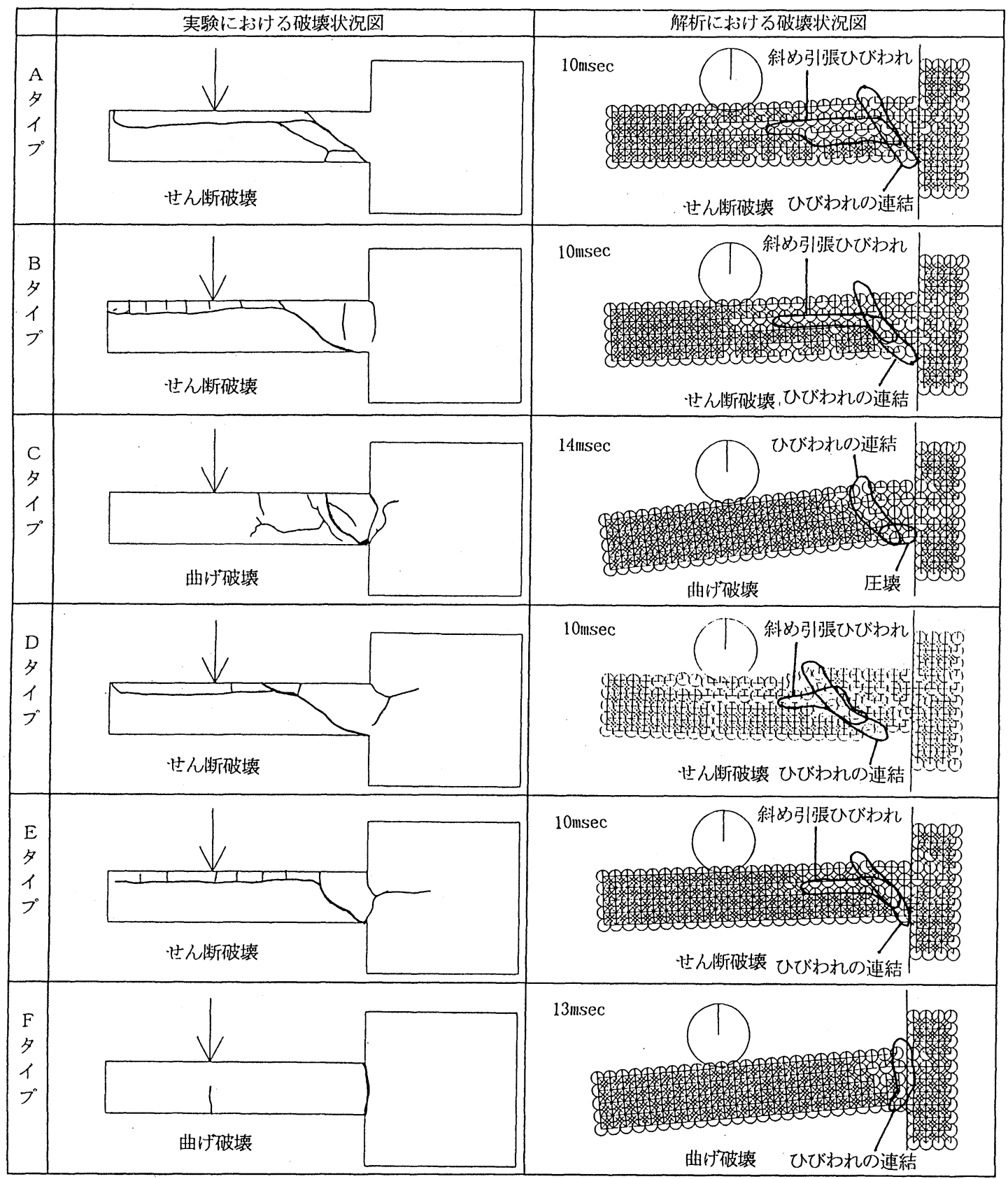

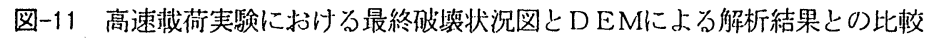

イプが，鉄筋破断による曲け破壊を起したのに対し，高 速載荷の場合は根元部裹面のコンクリートの圧壊に起 因するむのであり，このことは後述する解析結果（図10，11 のCタイプ）によっても検証される. また，図一 8(a)，（b)の単鉄筋において屯ほぼ同様な結果か得られ， $\mathrm{D}, \mathrm{E}$ タイプはせん断破壊，Fタイプは曲け破壊を生じ た.

さて, コンリート構造物の耐衝撃設計においてエネル
ギ一基準 ${ }^{13)}$ に基づく考え方がある．コンクリート製砂 防ダム袖部でも同様な適用を考えると終局限界までの 限界吸収エネルギ一量をいかに増大できるかが大きな 問題亡なる. 図-5で×印をつけた終局限界までの限界吸 収エネルギーを各タイプ毎に算出すると, 複鉄筋におい て高速載荷時にAタイプ 17.1 tonf ・ cm，Bタイプ 15.0 tonf $\bullet \mathrm{cm}, C$ タイプ $22.5 \mathrm{tonf} \cdot \mathrm{cm}$, 静的載荷時は, A夕イ プ5.9tonf $\bullet \mathrm{cm}$, B タイプ 7.5 tonf $\bullet \mathrm{cm}$, Cタイプ 35.9 
tonf・cm となる.これより，せ九断破壊したタイプ（A， B）の供試体では静的載荷時よりも高速載荷時の方か洏 力の上昇分が反映され限界吸収エネルギーが上昇する. これに反し, 曲け破壊したCタイプの供試体では高速載 荷時の限界吸収エネルギーが静的載荷よりも低い 傾向 が見られた.これは，終局変位が極度に低下したためと 考えられる．また，せん断破壊したA，B夕イプは曲げ 破壊したCタイプと比へ鉄筋比が大きいにもかかわら ず，限界吸収エネルギーは高速載荷および静的載荷時と もCタイプより小さいことか確認された：これを，引張 鉄筋比で除し鉄筋比当りの限界吸収エネルギーによっ て補蝵効果を見るとAタイプを $1.0(6.4 \mathrm{tonf} ・ \mathrm{~cm})$ として 比較すると，Bタイプは $1.9(11.9$ tonf $・ \mathrm{~cm}), \mathrm{C}$ タイプは 5. 2(33.6tonf・cm)となり，曲け破壊するCタイプが最む 効率の良い主鉄筋による補強となることが明確に見ら れる. 同様に，図-6における単鉄筋夕イプの限界吸収工 ネルギーを算出すると高速載荷時にDタイプ 16.4tonf・ $\mathrm{cm}, \mathrm{E} タ イ フ ゚ 7.7 \mathrm{tonf} \bullet \mathrm{cm}, \mathrm{F}$ タイプ $17.9 \mathrm{tonf} \cdot \mathrm{cm}$, 静的 載荷時は，Dタイプ 4.6 tonf $\bullet \mathrm{cm}$, Eタイプ 4.9 tonf $\bullet \mathrm{cm}$, Fタイプ 27.9tonf・cm となり，また，鉄筋比当りの限界 吸収エネルギーも複鉄筋とほぼ同様な結果となった。

以上より，主鉄筋による補強は，引張鉄筋比の大きい A， B（またはD， E ）タイプのようにコンクリートの せん断破壊により一気に破壊するものではなく, 鉄筋比 の小さいC（またはF）タイプのような曲け破壊するよ うに補強すべきであると考えられる。 しかし，曲け破壊 の場合は静的と比べ高速載荷時の限界吸収エネルギー が咸少する場合があり, 注意すべきことが確認された。 これは，曲け破壊において根元部の鉄筋の破断（静的載 荷）もしくはコンクリートの圧壊（高速載荷）による破 壊モードの違いと思われる.

\section{c)ひずみ応答データ}

図-9(a), (b), (c)に，一例として複鉄筋Aタイプの高 速載荷時における荷重，変位～時間関係および衝突裏面 根元部近傍の H5, H7 のひずみ〜時間関係を示す. 図-9(a) の荷重〜時間関係に3つの山が見られるが，上述のよう に，RCはりの振動によるもの之考えられる. 図-9(c) より，H5，H7 のひずみはいずれも縮側で $3500 \mu$ とな るが, 約 $9 \mathrm{msec}$ の時点で一挙にひずみが減少する.この 状態は斜めひび割れの発生により裏面のコンクリート の応力が開放され，ひずみが咸少したものと思われる. また，ひずみ応答の勾配はコンクリートに生じるひずみ 速度它を表わしており，この場合 $6 \mathrm{msec}$ の間に $3500 \mu$ に達したとすると宅 $=0.583 \fallingdotseq 10^{-0.23} / \mathrm{sec}$ となる. 一般に 土石流による巨礫の衝突速度は約 $5 \sim 6 \mathrm{~m} / \mathrm{sec}$ 程度であり, ひずみ速度としてはと் はせいぜい $10^{-1} \sim 10^{0} / \mathrm{sec}$ 程度と 考えられている ${ }^{15)}$. したがって，本実験のような高速 載荷実験によってR C スラブの動的挙動を調べておけ
ば十分と思われる. なお，斜めひび割れの発生によるせ ん断破壊に達したひずみ応答の時刻はひずみが激减し た $9 \mathrm{msec}$ 直後であり，このときを終局限界と定義して図 -9(b)に示す変位〜時間曲線の対応する変位を終局状態 として×印をつけた，以上の方法により図-5 から図-8 の×印は，ひずみゲージのデー夕を基につけたものであ る.

\section{d)破壊状況の考察}

写真-1 および図-10,11 の左側の図は静的および高速 載荷における最終破壊状况（図-5 8 の×印時）を示し たものである. これより, 複鉄筋は両載荷の場合ともA, $\mathrm{B}$ タイプは載荷点と根元部裏面との斜めひび割れが連 結したせん断破壊モ一ドを示しており，一方Cタイプは， 根元部の載荷側と裏面側とのひび割れが連結した曲げ 破壊モ一ドを示している. しかし，実験結果の最終破壊 状況図からだけでは，Cタイプの曲け破壊における静的 載荷之高速載荷の明瞭な違いは分からない，後述するD $\mathrm{EM}$ 解析および高速ビデオによってのみその違いを解 明できる。

単鉄筋のD，E，Fタイプの静的および高速載荷にお ける破壊状況も，複鉄筋夕イプとほぼ同じ破壊モードを 示していることもわかる. なお, 写真-1のD夕イプはせ ん断破壊によりはりの下側部分がずれ落ちてしまった ため，上側部分のみ残っているものである.

\section{3．RCはりの個別要素法による高速載荷解析}

実験で使用した供試体は，RCスラブで本来 3 次元解 析あるいは板解析をすべきであるが，2．の破壊状況で 考察したように板的破壊挙動よりもはり的破壊挙動の 方が支配的であるので，ここでは片持ちR C はりとして 2 次元解析を行うものとする.

\section{(1)本研究で用いた個別要素法の特色}

本研究で用いた個別要素法は, 従来の方法 ${ }^{16)}$ とほぼ 同様であるが，以下の点に特色がある.

\section{a)要素の結合条件}

連続体としての鉄筋コンクリートはりを離散的な個 別要素にモデル化すると, 互いに接触していても空間が 生じてしまうので，ここでは連続体を保持させるため, 結合ばね ${ }^{16)}$ の考え方を導入し，モデル化後の空間を埋 めるために斜め要素の組み合わせに対しても要素の結 合条件を設定した，つまり要素の結合条件は次式を満足 するとき結合しているものとみなす。

ただし， $R_{i j}$ : 要素 $\mathrm{i}$ と要素 $\mathrm{j}$ との間の距離, $r_{i}, r_{j}$ : 要素 $\mathrm{i}$ と要素 $\mathrm{j}$ の半径, $\beta$ : 結合パラメータで, 例えば

$$
R_{i j} \leqq \beta\left(r_{i}+r_{j}\right)
$$



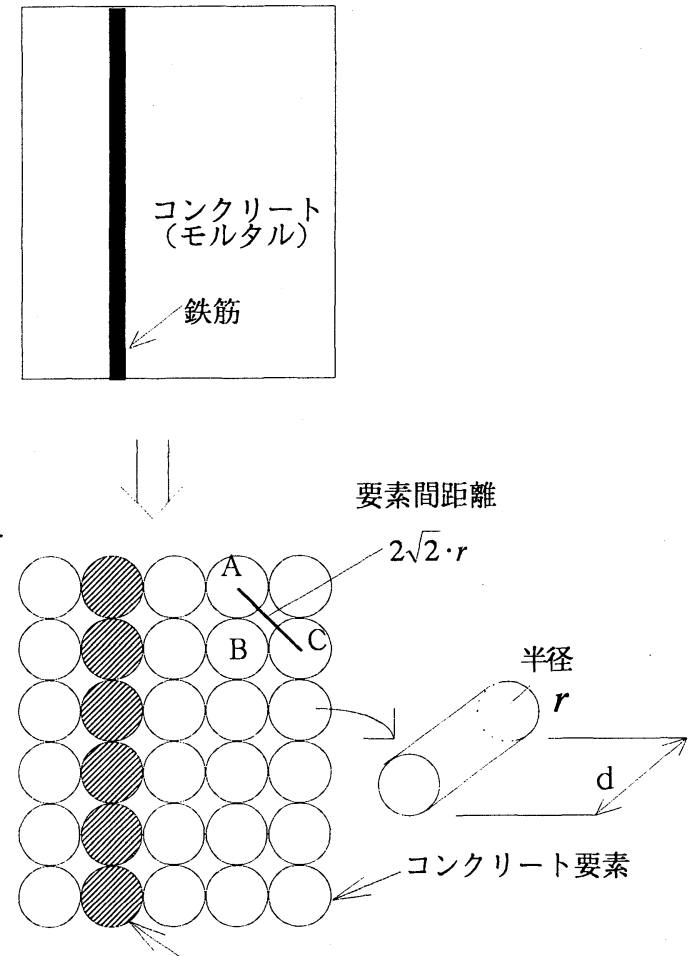

鉄筋入りコンクリート要素 図-12 要素モデル

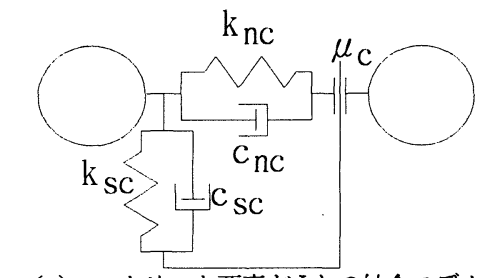

(a)コンクリート要素どうしの結合モデル

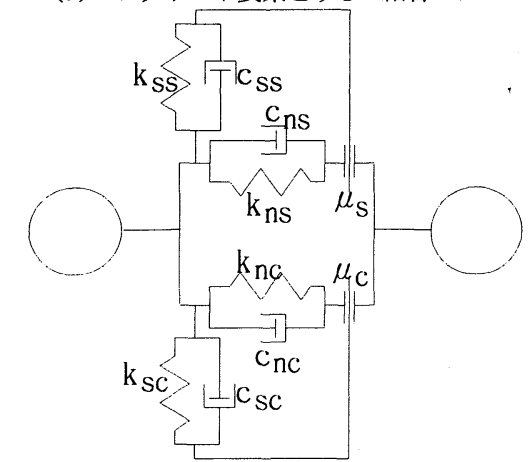

(b)鉄筋入りコンクリート要素どうしの結合モデル 図-13 結合モデル

図-12 の要素 $\mathrm{A}$ と要素C とは, 離れているが $R_{i j}=2 \sqrt{2} r$ であるので $\beta=\sqrt{2}$ とおくと式(1)を満足することにな る.よって, 要素 $\mathrm{A}$ 要素Cは離れてはいるが $\beta=\sqrt{2}$ の とき結合しているものとみなす.

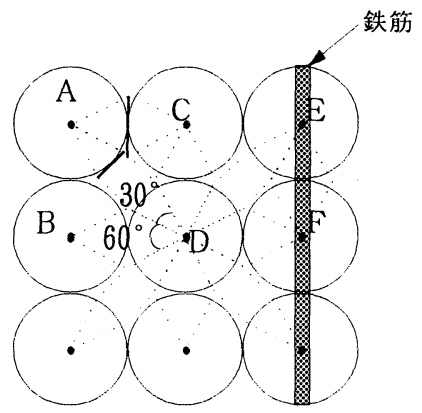

$\mathrm{AB}, \mathrm{AC}$

$\mathrm{A}_{\mathrm{ij}}=2 \mathrm{r} \cdot \mathrm{d} \cdot \tan 30^{\circ} \quad\left(\alpha=\tan 30^{\circ}\right)$

$\mathrm{AD}, \mathrm{BC}$

$\mathrm{A}_{\mathrm{ij}}=2 \mathrm{r} \cdot \mathrm{d} \cdot \tan 15^{\circ}\left(\alpha=\tan 15^{\circ}\right)$ $\mathrm{EF}$

$\mathrm{A}_{\mathrm{ij}}=2 \mathrm{r} \cdot \mathrm{d} \cdot \tan 30^{\circ} \quad\left(\alpha=\tan 30^{\circ}\right)$

図-14 有効接触面積の考え方 ${ }^{16)}$ ( $\mathrm{r}$ : 半径, $\mathrm{d}$ : 奥行き)

\section{b)ばね定数の設定の考え方}

各要素の作用力を表すため，まず，コンクリート要素 どうしの結合（例えば図-12 のAとBまたはAとC）で は，図-13(a)に示すような法線方向に，ばね $k_{n c}$ とダッ シュポット $c_{n c}$ を, 接線方向にはばね $k_{s c}$ とダッシュポッ ト $c_{s c}$ を設けた. また接線方向には，クーロンのすべり 条件を満足するスライダー $\mu_{c}$ を設けた.

次に，鉄筋入りコンクリート要素どうしの結合を別個 のばねによって表し, 独立した挙動を示すものとした。 すなわち, 法線方向にはコンクリート部分の $k_{n c}, c_{n c}$ お よび鉄筋部分の $k_{n s}, c_{n s}$, 接線方向にもコンクリート部 分の $k_{s c}, c_{s c}$ ，鉄筋部分の $k_{s s}, c_{s s}$ をそれぞれ設けた。 さらに，鉄筋入りコンクリート要素とコンクリート要素 との結合(例えば, 図-14のCとE)に関しては, 図-13(a) と同じコンクリート要素どうしの挙動を示すものとし， ばねとダッシュポットおよびスライダーを設けるもの とした.

\section{c)ばね定数の決定法}

一般に，個別要素法の最も大きな問題は，ばね定数等 の決定法である. ここでは，著者らの文献(16)のコンク リート構造の考え方をR C用に拡張して, 各要素どうし のばね定数 $k$ を，以下のようにコンクリート(モルタル) や鉄筋の材料定数であるヤング率 $E$ やポアソン比 $v$ 等 を用いて決定するものとした. この決定法は, 従来の方 法 ${ }^{7)}$ 亡は異なる本法独自のものである.

まずすべての要素を等円として，隣接する要素との結 合専有空間を有効接触面積 $A_{i j}$ として表し, 図-14 に示す ような幾何学的条件によって $A_{i j}$ を求める. すなわち, ばねか洧効に作用する接触面を考え，この有効接触面積 
$A_{i j}$ の值を次式のように求めた.

$$
A_{i j}=\ell \cdot d=2 r d \cdot \alpha
$$

ただし， $\ell:$ 有効接触面の長さ, $d$ : 要素の幅 (奥行き) $r$ : 要素半径, $\alpha$ : 有効接触面積パラメー夕 $(0 \leqq \alpha \leqq 1)$ で図-14 のように決定される ${ }^{16)}$. 例えば, 図-14のよう な要素配列で A B , A C, B D, CDの場合 $A_{i j}=2 r d$ $\cdot \tan 30^{\circ}$ で $\alpha=\tan 30^{\circ}$ となる.

次に，鉄筋コンクリート要素どうしの結合においては, この $A_{i j}$ を次のように鉄筋の有効接触面積 $A_{i j s}$ とコンク リートの有効接触面積 $A_{i j c}$ に分割する.

$$
A_{i j}=A_{i j c}+A_{i j s}
$$

ただし, $A_{i j c}$ : コンクリートの有効接触面積, $A_{i j s}$ : 鉄 筋の有効接触面積

この鉄筋の有効接触面積 $A_{i j s}$ は，実際の鉄筋断面積を用 い, コンクリートの有効接触面積 $A_{i j c}$ は式(3)より逆に以 下のように求める.

$$
A_{i j c}=A_{i j}-A_{i j s}
$$

よって, この $A_{i j c}$ と $A_{i j s}$ を用いて法線方向ばね力 $e_{n c}$, $e_{n s}$ と接線方向ばね力 $e_{s c}, e_{s s}$ がそれぞれ次式のように 表わされる ${ }^{16)}$.

コンクリート ;

$e_{n c}=\sigma_{c} A_{i j c}=E_{c} \varepsilon A_{i j c}=E_{c} \frac{u_{n}}{R_{i j}^{0}} A_{i j c}\left(=k_{n c} u_{n}\right)$

$e_{s c}=\tau_{c} A_{i j c}=\gamma G_{c} A_{i j c}=\frac{u_{s}}{R_{i j}^{0}} \frac{E_{c}}{2\left(1+v_{c}\right)} A_{i j c}\left(=k_{s c} u_{s}\right)$

鉄筋;

$e_{n s}=\sigma_{s} A_{i j s}=E_{s} \varepsilon A_{i j s}=E_{s} \frac{u_{n}}{R_{i j}^{0}} A_{i j s}\left(=k_{n s} u_{n}\right)$

$e_{s s}=\tau_{s} A_{i j s}=\gamma G_{s} A_{i j s}=\frac{u_{s}}{R_{i j}^{0}} \frac{E_{s}}{2\left(1+v_{s}\right)} A_{i j c}\left(=k_{s s} u_{s}\right)$

ただし， $E_{c}$ : コンクリートの弾性係数， $E_{s}$ : 鉄笳の弾性 係数, $G_{c}$ : コンクリートの横弾性係数, $G_{s}$ : 鉄筋の横 弾性係数, $\sigma_{c}$ : コンクリートの軸応力, $\sigma_{s}$ : 鉄筋の軸応 力, $\tau_{c}$ : コンクリートのせん断応力, $\tau_{s}$ : 鉄筋のせん断 応力, $\varepsilon$ : 法線方向ひずみ, $\gamma$ : せん断ひずみ, $v_{c}:$ コ ンクリートのポアソン比 $v_{s}$ : 鉄筋のポアソン比, $u_{n}$ : 法線方向変位, $u_{s}$ : 接線法方向変位, $R_{i j}^{0}$ : 要素間の初 期距離.

よって, ばね定数 $k_{n c}, k_{s c}, k_{n s}, k_{s s}$ は, 式(5)から次

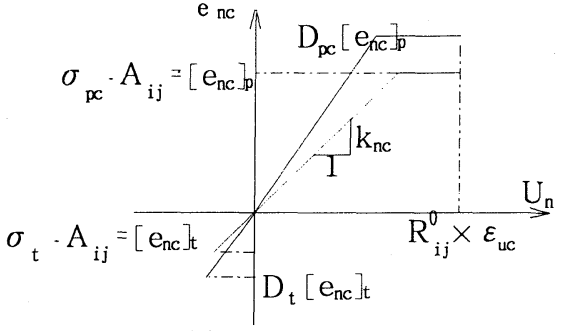

(a)コンクリート

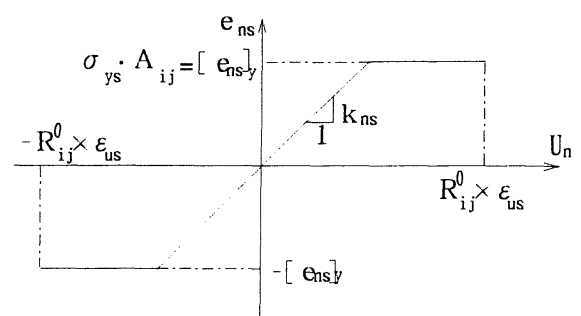

(b)鉄筋

図-15 法線方向の結合ばねの挙動およひ破壊

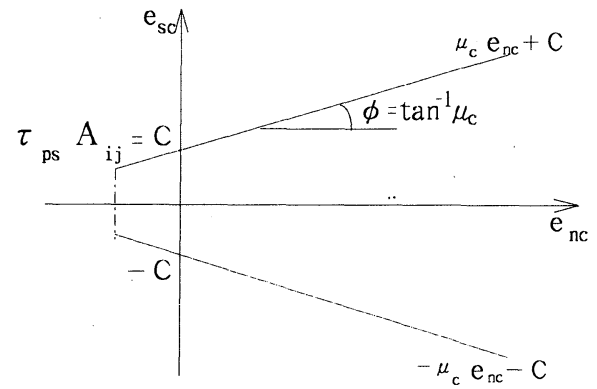

(a)接線方向の結合ばねの破壊

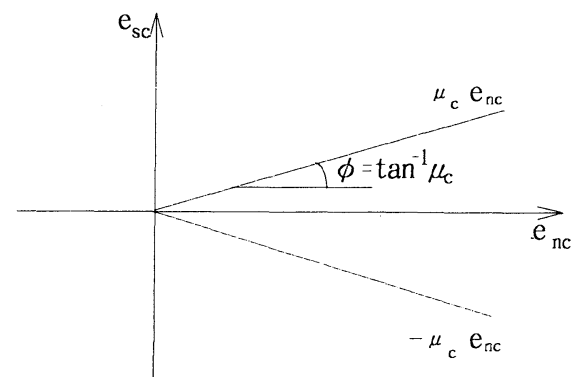

(b)再接触時における接線方向の結合ばねの滑り条件 図-16 コンクリートの破壊基準

式のように材料定数と要素配列の関数として決定され る. コンクリート；

$$
\begin{aligned}
& k_{n c}=E_{c} \frac{A_{i j c}}{R_{i j}^{0}} \\
& k_{s c}=E_{c} \frac{A_{i j c}}{R_{i j}^{0}} \frac{1}{2\left(1+v_{c}\right)}
\end{aligned}
$$




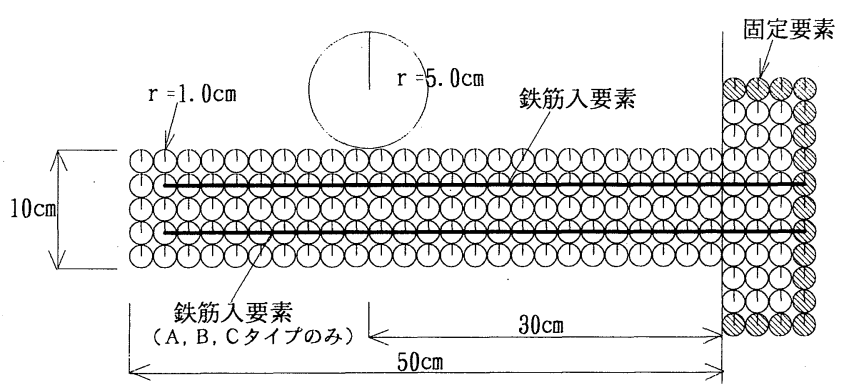

図-17 解析モデル

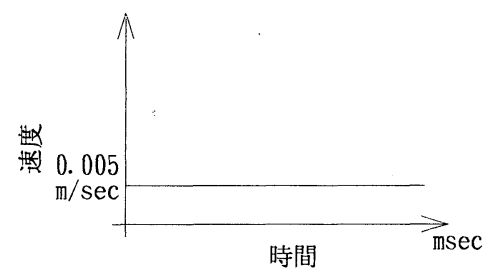

(a)静的載荷

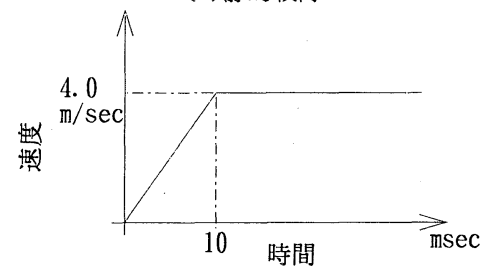

(b) 高速載荷

図-18 載荷速度〜時間関係

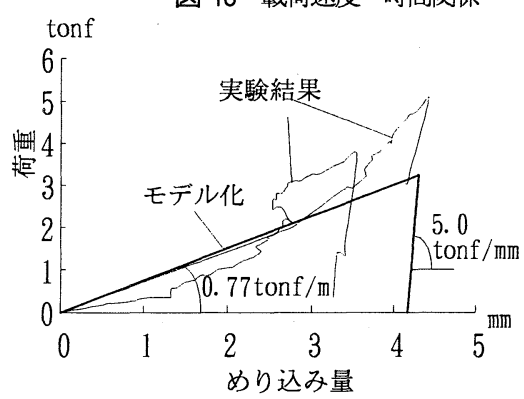

（a)局部のめり込み～荷重関係

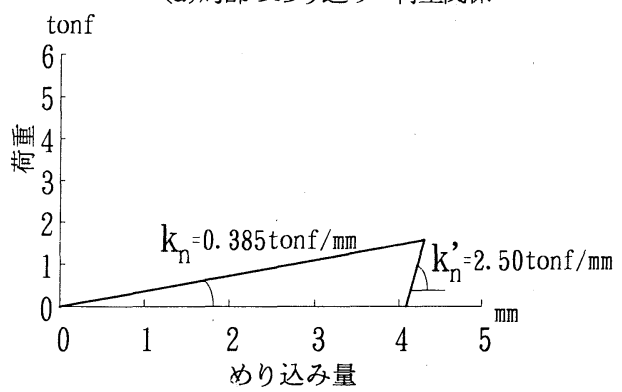

（b)載荷要素とコンクリート要素のばね定数

図-19 載荷点の局部ばね定数

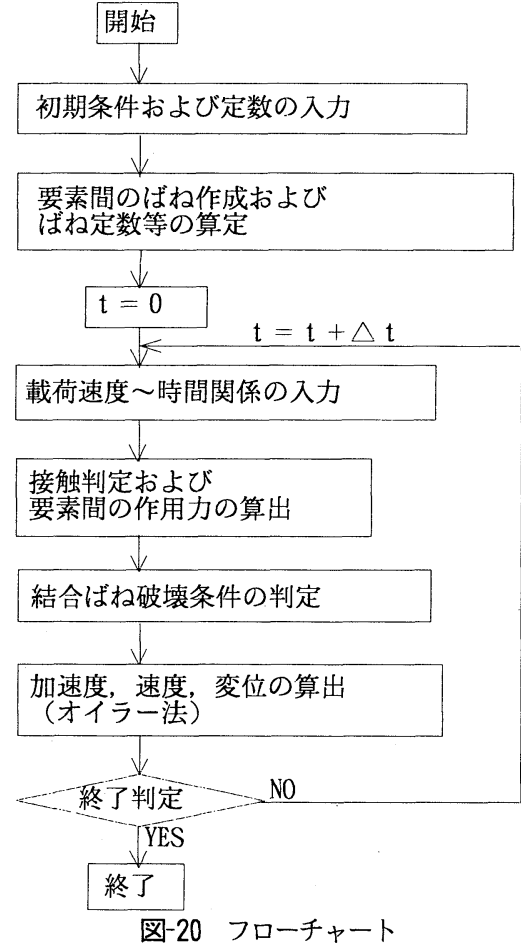

鉄筋；

$$
\begin{aligned}
& k_{n s}=E_{s} \frac{A_{i j s}}{R_{i j}^{0}} \\
& k_{s s}=E_{s} \frac{A_{i j s}}{R_{i j}^{0}} \frac{1}{2\left(1+v_{s}\right)}
\end{aligned}
$$

図-13に示したモデルでは，2要素間の変形に伴う力は, ばね力に加えて，ダッシュポットによる力がある.この ため変形速度が増大すると後述するばね力のひずみ速 度効果による増大分とダッシュポットによる力の増分 か発生することになる. このため, 後述するように材料 モデルにひずみ速度効果を考慮する場合には, ダッシュ ポットによる減衰項は無視するのか望ましい. しかし, 一般的に動的解析では，時間増分を用いるため解か伓安 定になり易く，減衰項にはこれを安定化させる作用があ る ${ }^{17)}$. 特に個別要素法では, オイラー法を用いるため, 解が不安定になり易い. よって本研究では, 計算の安定 化に必要で可能な限り小さな減衰項を与えるものとし, 減衰定数 $h=0.00005$ を用いて計算した.

\section{d)材料モデル}

FEMによる衝撃応答のためのR C 用の構成則は，従 来種々提案されている6)が未だ十分なものは見当たらな い.よって, ここでは 2 次元D EMによるR C用の構成 則として最も簡単な材料モデルを採用することとし，図 
表-5 解析における材料定数等

\begin{tabular}{|l|l|}
\hline モルタル \\
\hline ヤング率 $E$ & $1.94 \times 10^{5} \mathrm{kgf} / \mathrm{cm}^{2}$ \\
\hline ポアソン比 $v$ & 0.2 \\
\hline 内部摩擦角 $\phi$ & $35^{\circ}$ \\
\hline 静的最大圧縮強度 $\sigma_{p c, s}$ & $367 \mathrm{kgf} / \mathrm{cm}^{2}$ \\
\hline 压縮限界ひずみ $\varepsilon_{u c}$ & $3900 \mu$ \\
\hline 鉄筋 & \multicolumn{2}{|l|}{ ヤング率 $E$} \\
\hline ポアソン比 $v$ & $2.1 \times 10^{6} \mathrm{kgf} / \mathrm{cm}^{2}$ \\
\hline 降伏降伏点 $\sigma_{y s, s}$ & 0.3 \\
\hline 引張限界ひずみ $\varepsilon_{u s}$ & $0.343 \mathrm{kgf} / \mathrm{cm}^{2}$ \\
\hline その他 \\
\hline 時間増分 $\Delta t$ \\
\hline 結合パラメーター $\beta$ & $1.0 \times 10^{-7} \mathrm{sec}$ \\
\hline
\end{tabular}

-15, 16 に示す. まずコンクリートどうしの法線方向の ばねは，図-15(a)に示すように(1)引張では引張強度にお いて引張破壊し, クラックが発生する. (2)圧縮側では, 完全弾塑性亡し, 圧壊ひずみ $\varepsilon_{u c}(\fallingdotseq 3900 \mu)$ に達する 之圧壊する. (3)接線方向のせん断ばねについても完全弾 塑性とし，法線方向のばね力の関数として図-16(a)に示 す Mohr-Coulomb の破壊条件を用いた.ここで, 図中の Cは粘着力すなわち純せん断力 $\tau_{s} \cdot A_{i j}$ を表わす. また, 一旦引張破壊したばねは, 図-16(b)のように粘着力がゼ 口となり, 以後再接触時におけるせん断ばねの滑り条件 とした.

次に, 鉄筋入りコンクリート要素どうしの鉄筋の法線 方向の結合ばねは，図-15(b)に示すように完全弾塑性型 の応力〜ひずみ曲線を用い, 破断ひずみ $\varepsilon_{u s}$ に達した後, 応力は解放するものとした. また鉄筋のせん断ばねにつ いても完全弾塑性モデルを用いた.

ここで，この材料モデルにひずみ速度効果を以下のよ うに考慮する. まず，ひずみ速度 $(\dot{\varepsilon})^{18)}$ によって，コ ンクリートの材料定数が上昇する压縮強度比 $D_{p c}$, 弾性 率比 $D_{E}$ および引張強度比 $D_{t}$ は次式で表わされる. コンクリート圧縮時 :

$3.0 \times 10^{2} / \mathrm{sec}>\dot{\varepsilon}>30 \times 10^{-6} / \mathrm{sec}$

$$
\begin{aligned}
& \left.D_{p c}=\frac{\sigma_{p c, D}}{\sigma_{p c, S}}=\left(\frac{\dot{\varepsilon}}{30 \times 10^{-6}}\right)^{1.026 \frac{1}{5+0.0882 \sigma_{p c, S}}}\right) \\
& D_{E}=\frac{E_{c, D}}{E_{c, S}}=\left(\frac{\dot{\varepsilon}}{30 \times 10^{-6}}\right)^{0.02}
\end{aligned}
$$

$\dot{\varepsilon} \leqq 30 \times 10^{-6} / \mathrm{sec}$.

$D_{p c}=1$

$D_{E}=1$
コンクリート引張時 :

$3.0 \times 10^{2} / \mathrm{sec}>\dot{\varepsilon}>3.0 \times 10^{-6} / \mathrm{sec}$

$$
\begin{aligned}
& D_{t}=\frac{\sigma_{t, D}}{\sigma_{t, S}}=\left(\frac{\dot{\varepsilon}}{3.0 \times 10^{-6}}\right)^{1.016 \frac{1}{10+0.0588 \sigma_{p c, S}}} \\
& D_{E}=\frac{E_{c, D}}{E_{c, S}}=\left(\frac{\dot{\varepsilon}}{3.0 \times 10^{-6}}\right)^{0.02}
\end{aligned}
$$

$\dot{\varepsilon} \leqq 3.0 \times 10^{-6} / \mathrm{sec}$

$$
\begin{aligned}
& D_{t}=1 \\
& D_{E}=1
\end{aligned}
$$

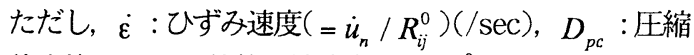
強度比, $\sigma_{p c, S}$ : 静的圧縮強度 $\left(\mathrm{kgf} / \mathrm{cm}^{2}\right), \sigma_{p c, D}$ : 動的俚 縮強度 $\left(\mathrm{kgf} / \mathrm{cm}^{2}\right), D_{E}$ : 弾性率比, $E_{S}$ : 静的弾性率 $\left(\mathrm{kgf} / \mathrm{cm}^{2}\right), E_{D}$ : 動的弾性率 $\left(\mathrm{kgf} / \mathrm{cm}^{2}\right), D_{t}$ : 引張強度 比, $\sigma_{t, S}$ : 静的引張強度 $\left(=0.245 \sigma_{p c, S}\right)^{19}\left(\mathrm{kgf} / \mathrm{cm}^{2}\right)$, $\sigma_{t, D}:$ 動的引張強度 $\left(\mathrm{kgf} / \mathrm{cm}^{2}\right)$.

これらの各比を用いて静的な材料定数を, 動的な材料定 数へ時間増分 $\Delta t$ ごと変更しながら高速載荷時の解析を 行うこととした. また，コンクリートの純せん断強度は 以下の式 ${ }^{19)}$ により算出することによりひずみ速度効果 を考慮する.

$$
\tau_{s}=D_{p c} \sigma_{p c, S}\left(0.252-0.000246 D_{p c} \sigma_{p c, S}\right)
$$

\section{e)解析モデルと載荷点のばね定数}

実験に使用した供試体を図-17 に示すようにはり部を 125 個, 固定部を 44 個の要素に(各半径 $1.0 \mathrm{~cm}$ )に分割し, 載荷要素(半径 $5.0 \mathrm{~cm}$ )を接触させて載荷した. ここで, 実験では，静的および高速載荷とも同じ載荷棒(先端形 状か淔径 $10 \mathrm{~cm}$ となっている)を使用しているので, 載荷 点のモデル化に当たっては図-17 のように半径 $5.0 \mathrm{~cm}$ の 載荷要素を当初 2 個の半径 $1.0 \mathrm{~cm}$ のコンクリート要素に 接触させ，接触ばねの速度〜時間関係を入力するもの之 した. すなわち，静的載荷では図-18(a)，高速載荷では 図-18(b)のような速度〜時間関係を与えた. また載荷要 素と接触コンクリート要素とを結ふ挶部ばね定数は静 的載荷実験における荷重〜めり込み量関係を用いた。 こで, めり込み量とは上変位と下変位との差であり, 静 的実験のデー夕を用いた.つまり実験で図-19(a)のよう な荷重〜めりこみ量曲線を得たので，この勾配を使用す る. しかし, 図-18(a)に示すように本解析モデルでは載 荷要素が 2 個のコンクリート要素と接触しているので, これを 1 個のコンクリート要素の局部ばね定数にする ため, 図-19(a)の勾配を $1 / 2$ として図-19(b)に示す $k_{n}$ お よび $k_{n}^{\prime}$ の值を局部ばね定数として用いた。 


\section{(2)解析手順}

以上の諸式ならびに解析モデルを用いて，通常の個別 要素法と同様にオイラ一法を用いて運動方程式を解く ことになる. その解析手順の概略をフローチャートに示 すと図-20に示すようになり，静的載荷之高速載荷解析 の相違は図-20の速度人力のところで図-18(a), (b)の速 度〜時間関係を入力する点である. その手順を示すと以 下のとおりである.

(1)まず各要素の座標 $x, y$, 要素幅 $d$, 各材料の弾性係 数等の材料定数および寸法, 時間増分 $\Delta t$ 等を入力する. (2)円柱要素の位置から結合ばねおよびそのばね定数を 決定する.

(3)載荷要素のみに載荷速度〜時間関係を与える.

(4)接触判定および要素間の作用力を算出する(ここで, ひずみ速度効果を考虑）。

(5)結合ばねの破壊条件をチェックする.

(6)各要素の加速度，速度，変位を算出する.

なお，時間増分 $\Delta t$ に関しては，Coolent条件 $\Delta t<$ $\left(R_{i j}\right)_{\min } / c_{0}$ （coはコンクリートの波動伝播速度で，ここ では $\mathrm{c}_{0}=3500 \mathrm{~m} / \mathrm{sec}$, 最小要素間距離 $\left(R_{i j}\right)_{\min }$ を $2 \mathrm{~cm}$ 用い た）を用いると $5.7 \times 10^{-6} \mathrm{sec}$ よるので，ここでは $\Delta t=1.0 \times 10^{-7}$ を採用した.

\section{4. 解析結果と実験結果の比較}

上記 3.で述べたR C 用の個別要素法による破壊解析 手法を用い，表-5に示す入力デー夕を与えて計算した.

\section{(1)破壊過程の比較}

図-21 は，高速載荷におけるAタイプの破壊過程を解 析結果亡高速ビデオ映像とを比較して示したものであ る.これより，高速ビデオでは $8 \mathrm{msec}$ 位まではクラック

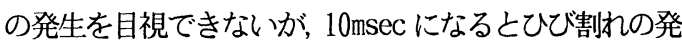

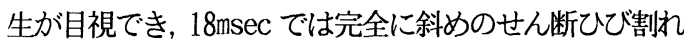
か観察される.この状況をDEMではかなり良くシミュ レートしており，特に $6 \mathrm{msec} て ゙$ て曲げにるひび割れが発 生しているが，8msec で高速ビデオで観察されなかった 斜め引張ひび割れが発生すると曲げによるひび割れの

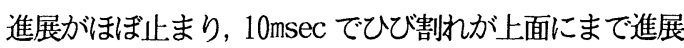
している様子を把握している. そして最後に局部めりこ みを含む斜めせん断ひび割れにより破壊していること がわかる.

図-22 は，同様に高速載荷におけるBタイプの破壊形 態を示したもので, 6msecではDEMの方が斜め引張ひ び割れを表示している. 10msecではビデオに写っている のと同様のひで割れをシミュレートしている. そして最

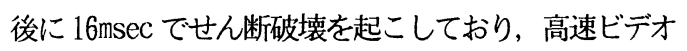
との対応により実に興味ある結果を示しており，本法の
特色ある結果といえる.

図-23 は, Cタイプの結果でA，Bタイプとは異なり， 根元部の載荷面から裏面へのひび割れ連結によって曲 け破壊を起こしている様子を観察することができる.す なわち, $6 \mathrm{msec} て ゙$ 根元部上面に引張ひび割れか溌生し,

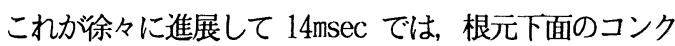
リートの圧壊によってひび割れが連結し，最終的に $22 \mathrm{msec}$ で曲け破壊を形成している. また. ビデオに見ら れる圧壊部分の飛び出しに関しても，DEMではうまく シミュレートしている. また図としては示していないが, 静的載荷および高速載荷のD, E, Fタイプについても, 写真-1 や図-10, 11 に示す破壊形態を非常に良くシミュ レートしている.

図-10，11 の右側の図に，DEMによる複鉄笳A，B， Cおよび単鉄筋D，E，Fタイプの静的および高速載荷 における最終破壊状況図（図-5〜8の×印をつけた終局 限界時における破壊状態で，高速ビデオによる最終状態 とは異なる）を実駼結果と比較して示したが, このDE Mによる結果は, 写真-1 にも示す破壊結果をほぼ良くシ ミュレートしている，ここで，図-10 で静的載荷のC夕 イプが鉄笳破断による曲け破壊を起したのに対し, 図一 11 の高速載荷のCタイプでは, 鉄筋は破断せずに根元部 裏面側のコンクリートの圧壊が生じており，この破壊モ 一ドの違いが図-7(b)の高速載荷のCタイプの終局変位 を減少させた原因と考えられられる.

以上，DEMにより破壊過程および最終破壊モ一ドを かなり良くシミュレートできることがわかった.

\section{（2）荷重～変位関係}

図-24(a), (b), (c)は, 複鉄筋A，B，Cタイプの静的載 荷時の荷重〜変位関係を示したもので, 荷重および変位 のいずれもかなりの精度でその傾向を良くシミュレー トしている. B，Cタイプの解析の最大荷重がやや実験 值よりも小さい値がでているが，これは，載荷点のモデ ル化亡局部ばね定数の值に帰因するもの亡思われる.

図-25(a), (b), (c)は, 複鉄筋A，B，Cタイプの高速載 荷時の荷重〜変位関係を示したものである. 静的載荷と 同様ほぼ実験結果を再現できているが，高速載荷時の実 験による振動成分を解析ではうまく表現していない点 および静的載荷と同様に最大荷重がやや小さい点が今 後の検討課題である. 高速載荷時の振動成分の問題は, 慣性力に起因すると考えられるが，これは図-18(b)の載 荷速度〜時間関係に振動の影響を取り入れることによ って, 実験と類似した結果が得られものと考えられ，こ の点については今後の課題と考えている.

以上より, 本研究で提案したDEMは, 各要素間の定 数を材料定数から決定できるうえ，静的載荷の場合には 定性的にも定量的にもほぼ良く荷重〜変位関係をシミュ 


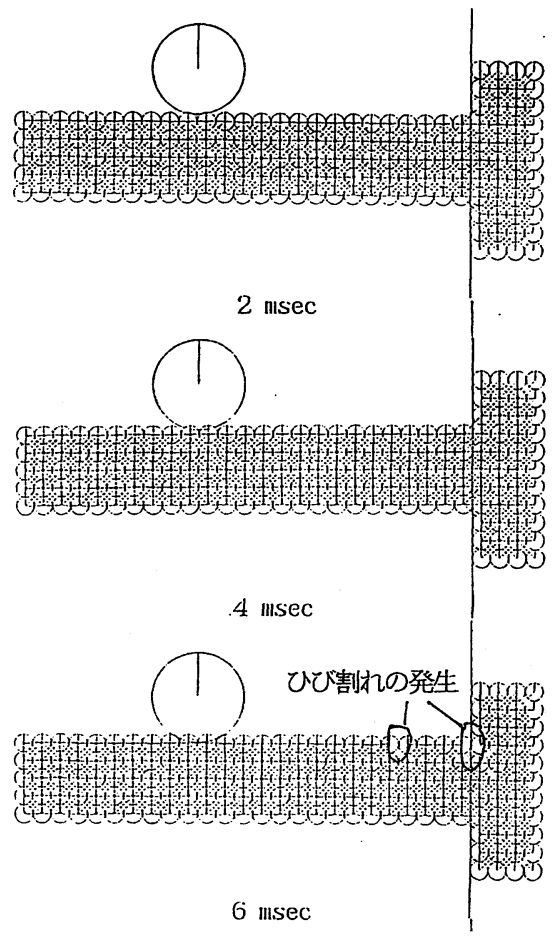

斜め引張ひび割れての

（T) 発生 (6)

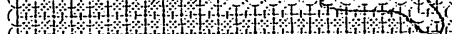

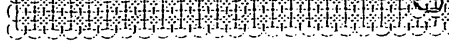

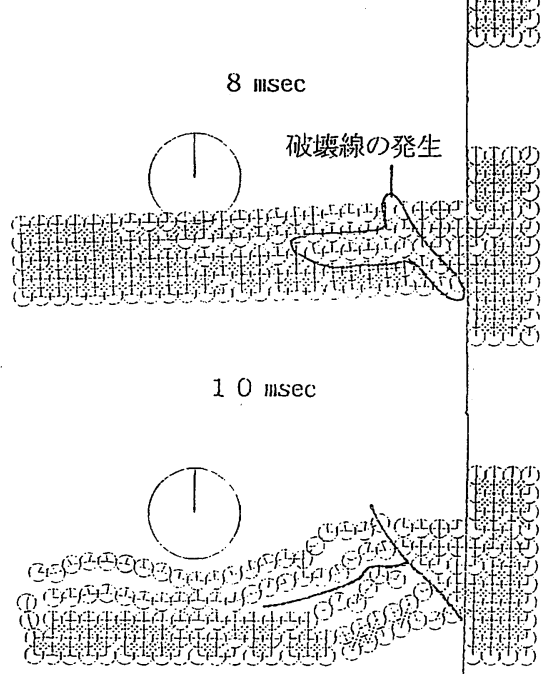

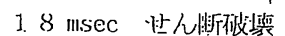

(a.) 所积析結果

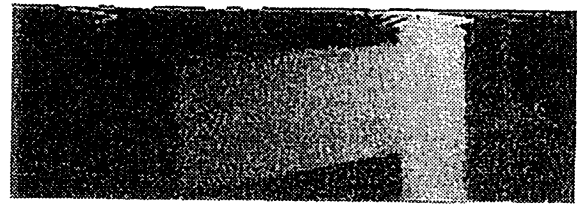

2 msec

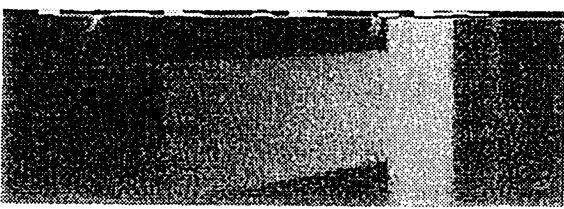

$4 \mathrm{msec}$

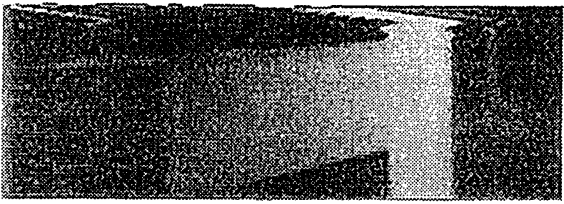

6 insec

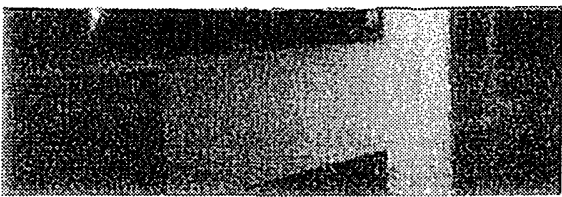

8 msec

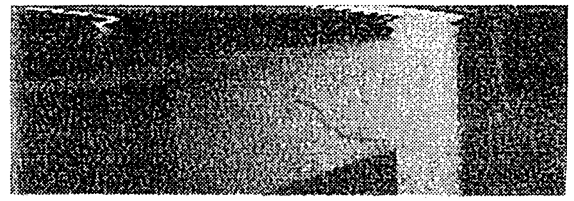

10 msec

破噮に至るひび割れて発生

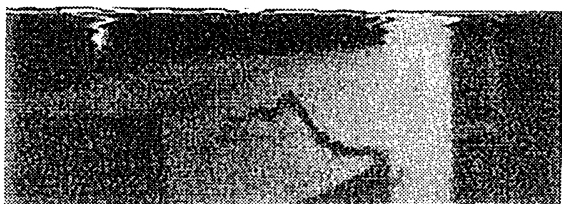

$18111 \mathrm{sec}$

(b) 高速に゙デ入阦像

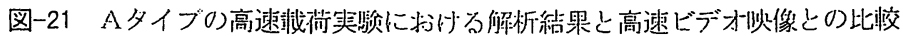




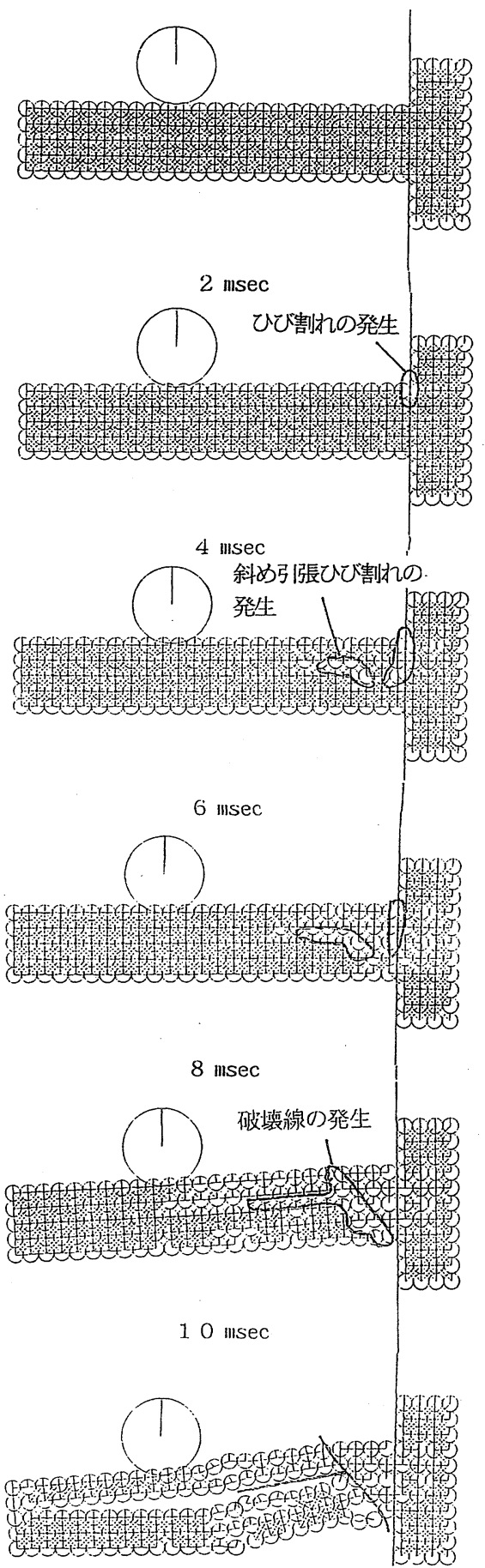

16 insec 世久断破壕

(a) 解析結果

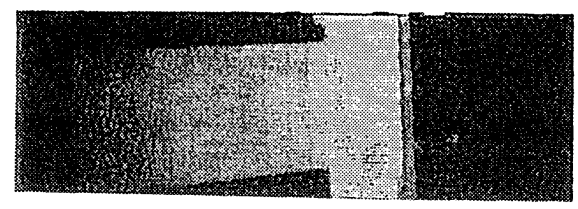

2 msec

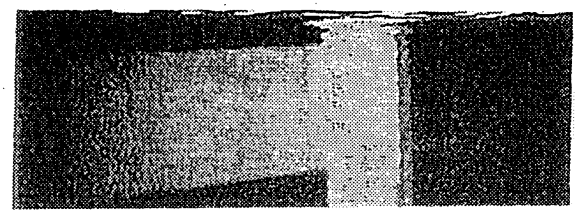

$4 \mathrm{msec}$

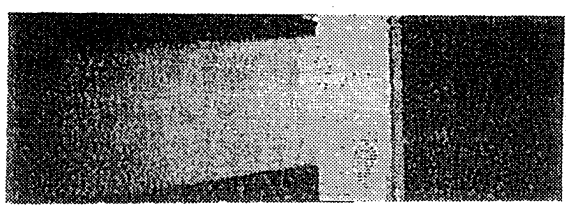

6 msec

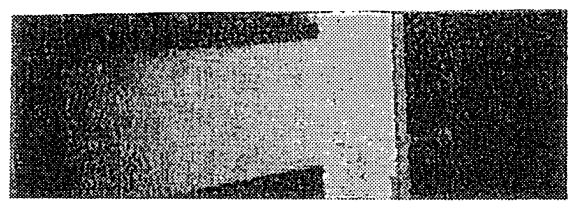

8 msec

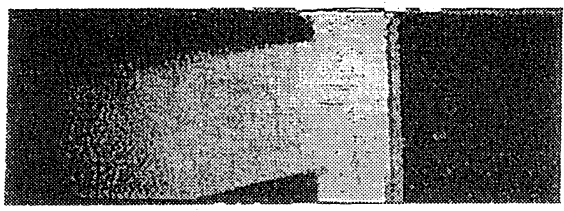

破壊に至るひび割れ発生

10 msec

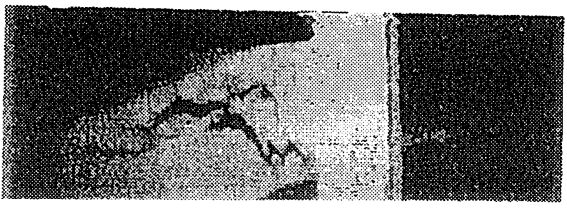

$16 \mathrm{msec}$

(b) 高速ビデオ唑像

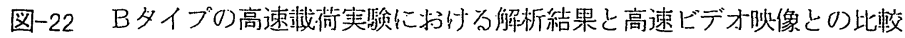



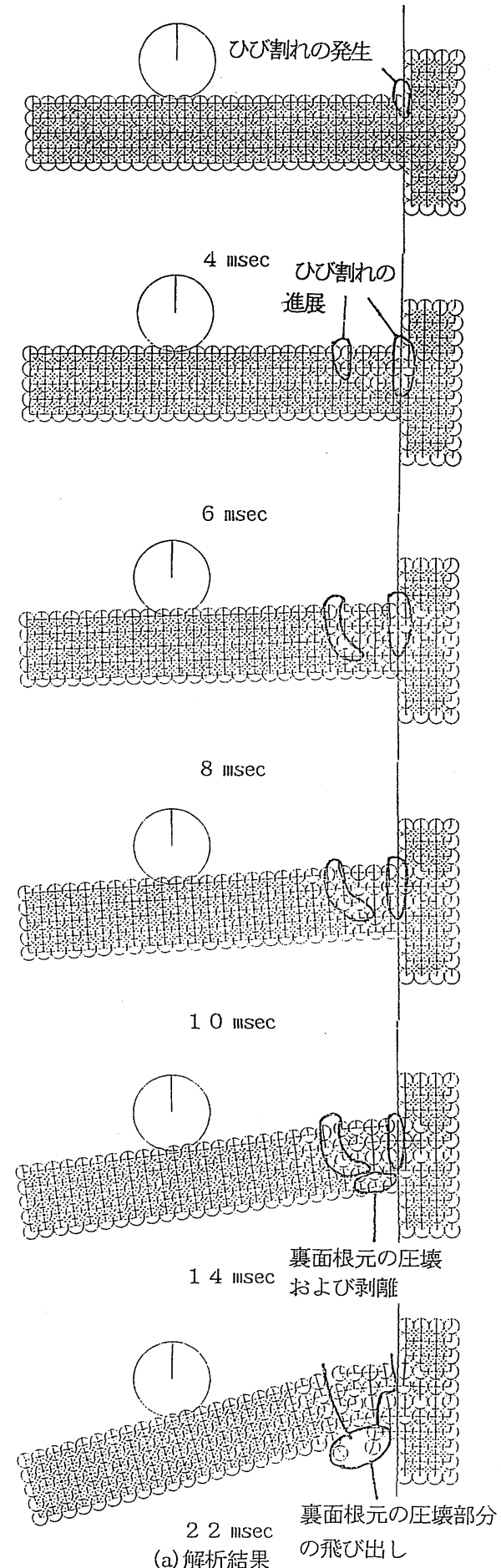

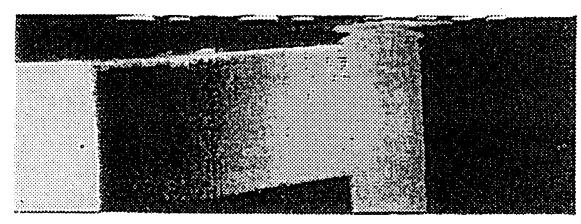

4 imsec

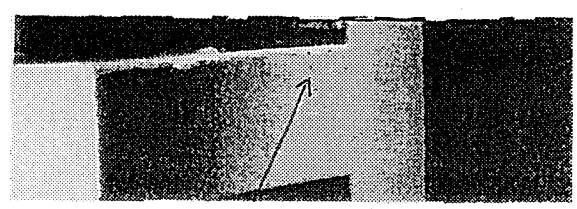

曲げによるひび割れ確認

6 insec

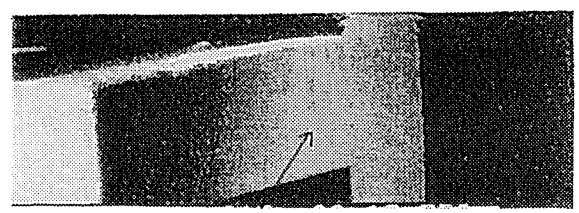

根元のひび割れてか裹面近くまで進展

$8 \mathrm{mssec}$

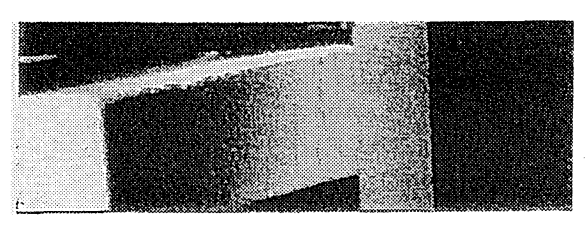

$10 \mathrm{mssec}$

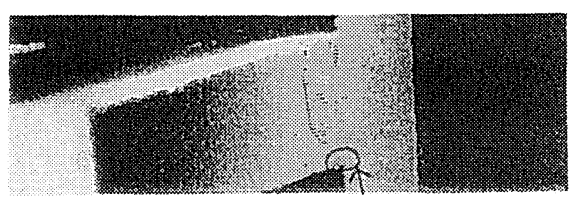

14 IIsec

裹面根元の压境 抢よび剥碓

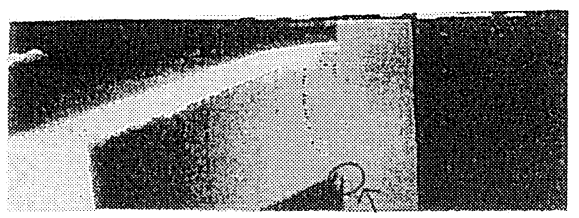

褧面根元の压墩部分の飛び出し 22 msec

(b) 高速ビデオ-旧像

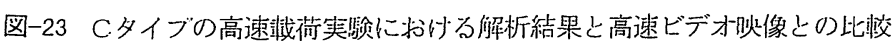




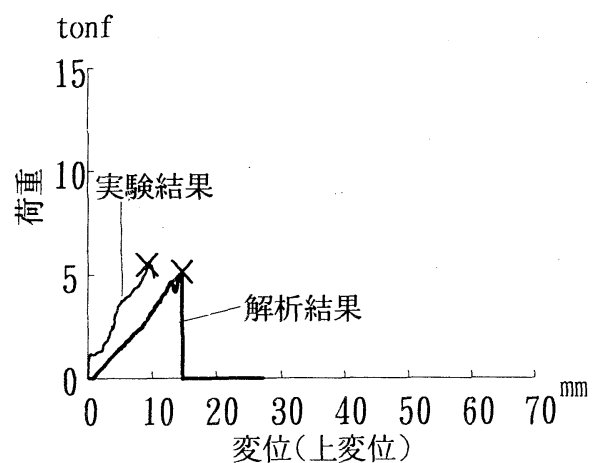

(a) Aタイプ

tonf

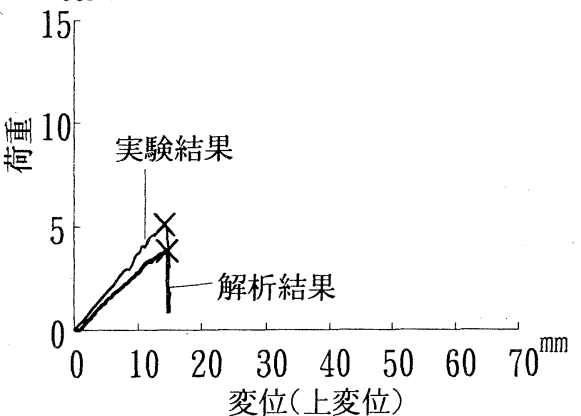

(b) Bタイプ

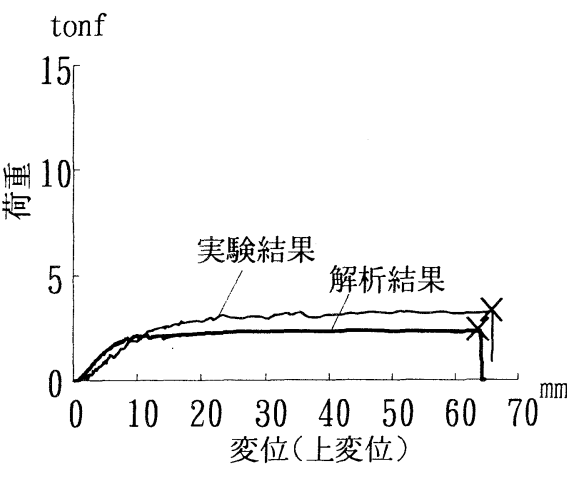

(c)Cタイプ

図-24 静的載荷における荷重～変位関係の比較

レートでき，高速載荷の場合も定性的に動的挙動をかな り把握できることが認められた．ただし，材料モデルや ひずみ速度効果，はりの振動の影響など今後検討する必 要があるものと考えられる.

\section{5. 結論}

本研究は，主鉄筋のみで補強したコンクリート製砂防 ダム模型としてR C 片持ちスラブを対象として, まず静 的および高速載荷実験を行い，その静的および動的挙動

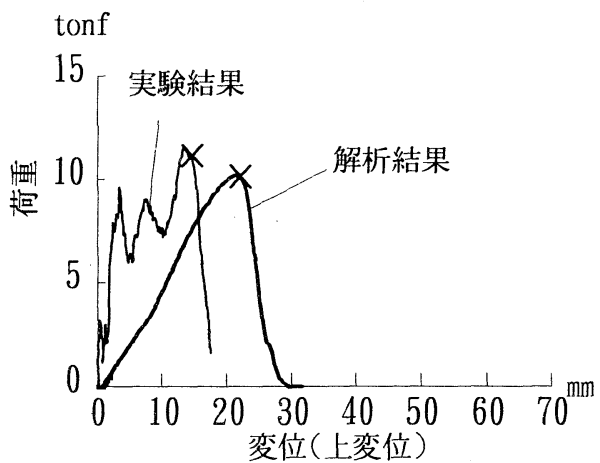

(a)Aタイプ

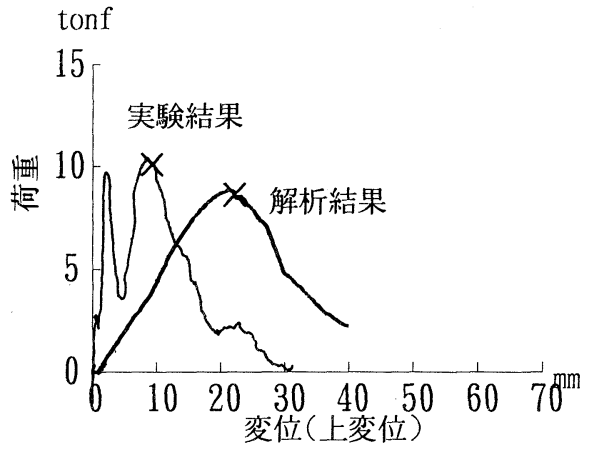

(b) Bタイプ

tonf

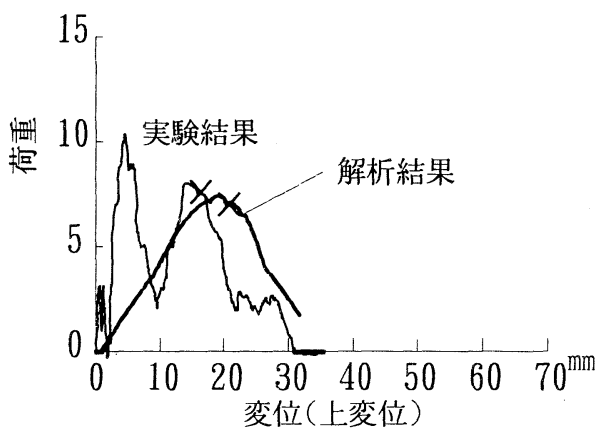

(c)Cタイプ

図-25＼cjkstart高速載荷における荷重～変位関係の比較

を調べるとともに，DEMによる破壊解析法により，破 壊過程および荷重〜変位関係をシミュレーションした ものである. その結果を再度要約すると以下のようにな る

（1）載荷速度か嗬重〜変位関係に及ぼす影響として 高速載荷における最大荷重は静的載荷に比し約 1.5 3.5 倍大きくなることが認められた. しかし, 変形性能 は高速載荷の場合, 主鉄筋量が少ないCタイプでは, 静 的に比べ大きく減少することが認められた。

（2）引張鉄筋比の影響としては，引張鉄筋比の大きい 
A， B夕イプ(複鉄筋)ではせん断破壊が生じ, 耐力およ び変形性能ともあまり差がないことが認められた，一方， 引張鉄筋比の小さいCタイプでは曲け破壊を生じ, 静的 載荷では大きな変形性能が認められた. これを限界吸収 エネルギ一の観点から見ると, 主鉄筋のみによる補強の 場合, 引張鉄筋比の大きい $\mathrm{A}, \mathrm{B}$ (またはD， E ）タイ プではせん断破壊により一気に破壊するので，限界吸収 エネルギーが小さく，一方の引張鉄筋比の小さいC（ま たはF）タイプでは曲け破壊するので限界吸収エネルギ 一が大きい：したがって，曲け破壊モ一ドを示すような 主鉄筋による補強力゙望ましいと考えられるが，この場合 も静的亡比べ高速載荷時の限界吸収エネルギーが減少 する場合があり, 注意すべきことが確認された。

（3）ひずみ応答デー夕の結果から, ひずみが一挙に変 化する時刻を終局限界時とし，このときの変位を終局限 界変位亡定義した。

（4）実験の破壊状況より, 鉄筋量の多いA，Bタイプ (複鉄筋)または $\mathrm{D}, \mathrm{E}$ タイプ(単鉄筋)は, 斜めせん断ひ び割れで最終破壊に達し，鉄筋量の少ないCタイプ(複 鉄筋)または $\mathrm{F}$ タイプ(単鉄筋)は，曲け破壊て壊れるこ とが判明した．これは，静的せん断耐力および曲け耐力 からもほぼ推測することができた。

（5）RC用のDEMを開発したが，本DEMでは，ば 小定数を材料定数や要素の配列に起因する有効接触面 積を用いて決定することができた.

（6）本DEMによる破壊過程と実験の高速ビデオによ る結果とを比較した結果，極めて良くシミュレートして いることがわかった. したがって，本DEMは，RCは りの破壊過程を追跡するうえで極めて良好な武器とし て使用できるのではないかと思われる。

（7）本DEMによる静的荷重～変位関係は実験結果と 極めて良く一致した. しかし, 高速載荷時の荷重〜変位 関係は荷重が実験值に比し小さい結果となった. しかし, 定性的には動的挙動をほぼ把握していると考えられる.

以上より, 今後の課題としては実験上さらに供試体の 数を多くして精度を上げること，またDEMについては ばね定数の決定法さらには各種の配列の方法やひずみ 速度効果の問題点が挙げられる.これらについてはさら に検討を重ねる予定である.

謝辞 : 本研究を行うにあたりご援助頂いた八千代エンジ ニアリング(株)水工部長下田義文氏に対し謝意を表し ます.

\section{参考文献}

1）下田義文，水山高久，石川信隆，古川浩平：巨础を受ける コンクリート製砂防ダム袖部の衝撃模型実験と被災例シミ ユレーション, 土木学会論文集, No. 450/I-20, pp.131-140,
1992. 7.

2）建設省河川局秒防部秒防課：土石流対策指針(案)，1989年 10 月.

3）鈴木真次, 石川信隆, 水山高久 石川芳治, 古川浩平: 鉄 筋コンクリート製仯防ダム袖部の終局限界状態に関する実 験的研究，土木学会論文集，No. 522/VI-28, pp. 107-118, 1995. 9 .

4）高橋芳彦，大野友則，太田俊昭，日野伸一：高速載荷を受 ける鉄筋コンクリートはりの終局限界変形量推定法, 土木 学会論文集，No. 432/ I -16, pp. 99-110, 1991.7.

5）藤井学, 宮本文穂, 森川英典 : 衝撃荷重を受ける鉄筋コン クリートはりの力学的挙動に関する基䃈的研究，士木学会 論文集，No. 360/V-3，pp.99-110，1985. 8.

6）井元勝慶，大野友則，佐々木晃，小暮幹太 : 重鍾落下衝突 を受けるRCはり部材の衝撃挙動之衝撃応答解析における 材料の非線形特性, 構造工学論文集，Vol. 41A，pp. 1201-1212, 1995.3

7）森川博司，澤本佳和，小鹿紀英 : 個別要素法を用いたコン クリートの破壊解析, 日本建築学会構造系論文集, 第 473 号, pp. 127-135, 1995. 7.

8）園田恵一郎, 鬼頭宏明，松浦幹佳：RC門形落石覆工の衝 撃破壊解析, 第2 回落石等による衝撃問題に関するシンポ ジウム講演論文集，土木学会，pp. 224-229，1993.6.

9）岸徳光、三上浩, 西弘明, 小山田欣裕 : 横方向衝撃力を受 けるR C 橋脚模型の破壊形状之耐衝擊性，構造工学論文集， Vol. 42A, pp. 1247-11254, 1996. 3.

10)伊藤干浩, 白井孝治, 大沼博志 : 剛体飛来物の衝突に対す る鉄筋コンクリート構造物の設計評価式，土木学会論文集， No. 507/I-30, pp. 201-208, 1995. 1.

11)三上敬司，三上浩，松岡健一，能町純雄 : 重鍾落下衝撃を 受ける単鉄筋 R C 床板の耐衝撃挙動に関する実験的研究。 構造工学論文集、Vol.40A，pp. 1619-1630, 1994.3.

12)桝谷浩，梶川康夫，玉村茂樹 : 個別要素法による鉄筋コン クリート部材の衝撃挙動解析, 構造工学における数值解析 シンポジウム論文集，日本鋼構造協会，第18巻，pp. 17- 20, 1994. 7.

13)土木学会 : 構造物の破壊挙動と設計法, 第皿篇, pp. 56-60, 1995. 8.

14)二羽淳一郎，山田一宇，横沢和夫，岡村甫 : せ九断補強䇴 を用いないRCはりのせん断強度式の再評価，土木学会論 文集，No. 372/V-5，pp.167-176，1986.8.

15)建設省土木研究所仯防部䏚防研究室: 土木研究所資料富士 土石流衝撃力実験報告書( II)，ISSN 0386-5878土研資料第 1662号, 1982. 3.

16)下田義文，鈴木真次，石川信隆，水山高久，古川浩平：個 別要素法によるコンクリート製砂防ダムの衝撃破壊シミュ レーション, 土木学会論文集，No. 480/VI-21，pp. 97-106, 1993. 12.

17)MARC Special Topics Course Nonlinear Dynamics Tokyo, A AMARC, 1984.2.

18)CEB : CEB-FIP Model Code 1990, First Draft, CEB Bulletin D'information No. 195, 1990.

19)村田二郎，長滝重義，菊川浩治 : 土木材料コンクリート， 共立出版，pp. 94-98，1989. 3.

(1996. 6. 6受付) 


\title{
DYNAMIC BEHAVIOR OF CONCRETE CHECK DAM WING MODEL WITH LONGITUDINAL REINFORCEMENT UNDER HIGH SPEED LOADING AND FAILURE ANALYSIS BY DISTINCT ELEMENT METHOD
}

\author{
Shinji SUZUKI, Nobutaka ISHIKAWA, Yoshiharu ISHIKAWA, \\ Takahisa MIZUYAMA and Kohei FURUKAWA
}

This paper presents both experimental and analytical approaches for the investigation of dynamic behavior of concrete check dam wing model with longitudinal reinforcement under high speed loading like debris flow. First, static and high speed loading tests were performed for six types of specimen in which the area of longitudinal reinforcement has been changed in the double and single concrete check dam wing models. It was found from the tests that the shear failure modes were seen in the specimens with strong longitudinal reinforcement, but the flexural failure mode was resulted in the specimen with weak longitudinal reinforcement. Second, the distinct element method has been developed by using the material constants and the effective sectional area. It was confirmed that the proposed method could simulate well the failure process in the test results taken by high speed video. 